\title{
Polymer Coated Oncolytic Adenovirus to Selectively Target Hepatocellular Carcinoma Cells
}

\author{
Mariangela Garofalo ${ }^{1, *,+} \oplus$, Federica Bellato ${ }^{1,+}{ }^{\dagger}$, Salvatore Magliocca ${ }^{1}$, Alessio Malfanti ${ }^{2}$, Lukasz Kuryk ${ }^{3,4}{ }^{1}$, \\ Beate Rinner ${ }^{5}$, Samuele Negro ${ }^{6}$, Stefano Salmaso ${ }^{1}{ }^{(\mathbb{D}}$, Paolo Caliceti ${ }^{1}$ and Francesca Mastrotto ${ }^{1, * \mathbb{C}}$ \\ 1 Department of Pharmaceutical and Pharmacological Sciences, University of Padova, Via F. Marzolo 5, \\ 35131 Padova, Italy; federica.bellato@unipd.it (F.B.); magliocca.s@gmail.com (S.M.); \\ stefano.salmaso@unipd.it (S.S.); paolo.caliceti@unipd.it (P.C.) \\ 2 Université Catholique de Louvain, Louvain Drug Research Institute, Advanced Drug Delivery and \\ Biomaterials, Avenue Mounier, 73 bte B1 73.12, 1200 Brussels, Belgium; alessio.malfanti@uclouvain.be \\ 3 Department of Virology, National Institute of Public Health-National Institute of Hygiene, Chocimska 24, \\ 00-791 Warsaw, Poland; lkuryk@pzh.gov.pl \\ 4 Clinical Science, Targovax Oy, Saukonpaadenranta 2, 00180 Helsinki, Finland \\ 5 Division of Biomedical Research, Medical University of Graz, Roseggerweg 48, 8036 Graz, Austria; \\ beate.rinner@medunigraz.at \\ 6 Department of Biomedical Sciences, University of Padova, Via Ugo Bassi 58/B, 35131 Padova, Italy; \\ samuele.negro@unipd.it \\ * Correspondence: mariangela.garofalo@unipd.it (M.G.); francesca.mastrotto@unipd.it (F.M.); \\ Tel.: +39-04-9827-5710 (M.G.); +39-04-9827-5708 (F.M.) \\ check for \\ + These authors contributed equally to this work.
} updates

Citation: Garofalo, M.; Bellato, F.; Magliocca, S.; Malfanti, A.; Kuryk, L.; Rinner, B.; Negro, S.; Salmaso, S.; Caliceti, P.; Mastrotto, F. Polymer Coated Oncolytic Adenovirus to Selectively Target Hepatocellular Carcinoma Cells. Pharmaceutics 2021, 13, 949. https://doi.org/10.3390/ pharmaceutics13070949

Academic Editor:

Carlos Alonso-Moreno

Received: 11 May 2021

Accepted: 18 June 2021

Published: 24 June 2021

Publisher's Note: MDPI stays neutral with regard to jurisdictional claims in published maps and institutional affiliations.

Copyright: (c) 2021 by the authors. Licensee MDPI, Basel, Switzerland. This article is an open access article distributed under the terms and conditions of the Creative Commons Attribution (CC BY) license (https:// creativecommons.org/licenses/by/ $4.0 /)$.
Abstract: Despite significant advances in chemotherapy, the overall prognosis of hepatocellular carcinoma (HCC) remains extremely poor. HCC targeting strategies were combined with the tumor cell cytotoxicity of oncolytic viruses (OVs) to develop a more efficient and selective therapeutic system. OVs were coated with a polygalactosyl-b-agmatyl diblock copolymer $\left(\mathrm{Gal}_{32}\right.$ - $b$-Agm $\left.{ }_{29}\right)$, with high affinity for the asialoglycoprotein receptor (ASGPR) expressed on the liver cell surface, exploiting the electrostatic interaction of the positively charged agmatine block with the negatively charged adenoviral capsid surface. The polymer coating altered the viral particle diameter (from 192 to $287 \mathrm{~nm}$ ) and zeta-potential (from -24.7 to $23.3 \mathrm{mV}$ ) while hiding the peculiar icosahedral symmetrical OV structure, as observed by TEM. Coated OVs showed high potential therapeutic value on the human hepatoma cell line HepG2 (cytotoxicity of $72.4 \% \pm 4.96$ ), expressing a high level of ASGPRs, while a lower effect was attained with ASPGR-negative A549 cell line (cytotoxicity of $54.4 \% \pm 1.59$ ). Conversely, naked OVs showed very similar effects in both tested cell lines. $\mathrm{Gal}_{32}-b-$ Agm $_{29}$ OV coating enhanced the infectivity and immunogenic cell death program in HepG2 cells as compared to the naked OV. This strategy provides a rationale for future studies utilizing oncolytic viruses complexed with polymers toward effective treatment of hepatocellular carcinoma.

Keywords: oncolytic adenovirus; hepatocellular carcinoma; cationic glycopolymers; tumor targeting; cancer therapies; ASGPR

\section{Introduction}

Hepatocellular carcinoma (HCC) is a primary liver malignancy and the fourth leading cause of death annually [1-3], being very aggressive and the most frequent solid tumor of the liver. Globally, $80 \%$ of the HCC cases derive from the two most important risk factors, hepatitis B virus (HBV) and hepatitis C virus (HCV) infections [4], while only a minor proportion of HCC can be ascribed to non-viral related factors, such as excessive alcohol consumption, iron overload syndrome, aflatoxin exposure, and also diabetes with subsequent development of non-alcoholic steatohepatitis [5]. Importantly, HBV and HCV infection are responsible for the onset of chronic liver injury, which could further develop 
into cirrhosis and progress to HCC. In particular, HBV viral proteins hold oncogenic potential, and their DNA can integrate into the host cells genome, directly transforming healthy hepatocytes into cancer cells [6].

Despite several advances in its management, HCC is a highly refractory cancer, resistant to conventional treatments that often provide only marginal survival benefits along with undesirable side effects [7]. Several strategies have therefore been investigated to improve the prognosis of patients affected by HCC [8].

So far, nanotechnology-based approaches to engineering highly specific targeted drug delivery systems able to diagnose, image, and treat HCC have been developed. However, although successful results being obtained with various targeted nanoparticles, their clinical application encounters several hurdles related to their physicochemical instability, poor biopharmaceutical behavior, off-targeting toxicity, uncontrolled drug release profile, etc. [9]. Therefore, there is a high demand to continue the investigation into new therapeutic systems and materials that can offer new opportunities for HCC treatment.

In this realm, a novel and effective approach to treating HCC can be represented by oncolytic virotherapy, which embodies a selective and powerful tool for cancer treatment. Oncolytic adenoviruses (OVs) are able to selectively replicate in tumor cells while sparing the healthy ones [10-14], inducing cytotoxic effects only in cancer cells by selective tumor cell lysis and boosting antitumor immunity [15-20]. In addition, OVs have shown encouraging clinical outcomes in terms of safety and efficacy [21], thus entering into the golden age of their utilization since IMLYGIC ${ }^{\mathrm{TM}}$ (T-VEC/Talimogene Laherparepvec) was approved, both in the United States and Europe, for the treatment of advanced-stage melanoma. T-VEC is a genetically modified herpes simplex-derived chimeric [22], and its tumor cell specific cytotoxicity is enforced by the virus-driven expression of human granulocyte-macrophage colony-stimulating factor (GM-CSF), which further stimulates the immune system.

The use of OVs for the treatment of HCC has recently gained increased attention due to preliminary studies showing its potential alone or in combination with chemotherapy [23]. For instance, Zou et al. recently reported that OVs associated with quercetin have a synergistic effect on the reduction of HCC growth and tumor volume in mice injected with HuH-7 hepatocyte-derived carcinoma cells [24]. Yoon et al. described the engineering of an OV to preferentially drive OV replication and cell killing in hepatocellular carcinoma (HCC) [25]. OVs have also been used for gene-targeted oncolytic viral therapy in HCC, a novel strategy based on the generation of viral vectors engineered with anticancer genes that selectively infect and kill cancer cells while having no toxic effect on the healthy ones [23].

However, there are some major limitations to the systemic delivery of OVs, including non-specific organ distribution and the production of neutralizing antibodies (NAbs) [26,27]. Therefore, proper OV strategies must be set up to increase OV disease organ disposition, enhance cell targeting and uptake, and reduce systemic immune response.

Among the strategies developed by nanotechnology to enhance the therapeutic performance of nanoparticles for drug delivery, surface decoration with bioactive polymers seems to be an interesting option to bestow cell selectivity and protection from inactivating agents on OVs. Accordingly, polysaccharides could be used to target the asialoglycoprotein receptors (ASGPRs), which are exclusively overexpressed by liver cells and bind galactose with high affinity and deliver OVs to hepatocellular carcinoma cells while reducing the off-organ disposition $[28,29]$. Therefore, the combination of liver cell targeting conveyed by galactosyl decoration of OVs with the ability of OVs to replicate only in cancer cells results in therapeutic systems with synergistic double selectivity.

Based on this hypothesis, we have designed a novel diblock copolymer constituted by a poly-galactose-based block for ASGPR targeting and a poly-agmatine cationic block for anchoring the copolymer to the negative OV surface. The copolymer was used for coating the adenovirus Ad5/3-D24-ICOSL (OV), and physicochemical features of the polymer-coated OV (PC-OV) were evaluated by dynamic light scattering (DLS), zeta 
potential analysis, and transmission electron microscopy (TEM). In vitro biological studies were carried out using human hepatoma cell line HepG2, which expresses high levels of ASGPRs, and adenocarcinoma human alveolar basal epithelial A549 cells lacking ASGPR expression. The cell selectivity, cytotoxicity, infectivity, immune-reactivity of PC-OV were comparatively evaluated with respect to naked OV (uncoated), copolymer alone, and a mixture of naked OV and copolymer separately added to the cell culture.

\section{Materials and Methods}

\subsection{Materials}

Acryloyl chloride, Agmatine sulfate, Carbon disulfide, Ethanethiol, 4,4'-azobis (cyanopentanoic acid), N-hydroxyethyl acrylamide, n-Butyl acrylate, 2,2'-azobis[2-(2imidazolin-2-yl)propane]dihydrochloride (VA-044), 1,4-Dioxane, Dimethylsulfoxide deuterated, Boron trifluoride diethyl etherate, Extravidin-peroxidase, Deuterium oxide, analytical grade solvents, salts, cyanuric chloride, and silicagel (60 ̊, particle size 35-70 $\mu \mathrm{m})$, were obtained from Sigma-Aldrich (St. Louis, MO, USA) and Fisher Scientific (Hampton, NH, USA). $\alpha$-D-Galactose pentaacetate was purchased from Apollo Scientific (Stockport, UK). Analytical thin-layer chromatography (TLC) was carried out on aluminum sheets coated with silica gel obtained from MACHEREY-NAGEL GmbH \& Co. KG (Düren, Germany). Dialysis membranes (MWCO 3.5 and $5 \mathrm{kDa}$ ) were provided by Prodotti Gianni S.r.l. (Milano, Italy). Cell culture media and reagents, phosphate-buffered saline (PBS), paraformaldehyde (PFA), and DAPI were purchased from Sigma-Aldrich (St. Louis, MO, USA), Fisher Scientific (Hampton, New Hampshire, USA), or Gibco ThermoFisher Scientific (Waltham, MA, USA). Adenovirus primary antibody 8C4 was obtained from Novus Biologicals. Biotin-SP-conjugated antibody was purchase from Jackson Immunoresearch.

\subsection{Nuclear Magnetic Resonance}

A Bruker DPX400 Ultrashield $400 \mathrm{MHz}$ (Billerica, MA, USA) was used for the monomers and polymers' characterization. The data were processed with MestReNova software (v6.0.2-5475, 2009, Mestrelab Research S.L., Santiago de Compostela, Spain).

\subsection{Gel Permeation Chromatography (GPC)}

The polymers' molecular weight and polydispersity index (Đ) were assessed by GPC analysis with Malvern Viscotek TDA302 system (Malvern, UK) equipped with a Refractometer (RI), a Low-Angle Light Scattering (LALS), a Right-Angle Light Scattering (RALS), and a Differential Viscosimeter (Visc) and thermostated at $40{ }^{\circ} \mathrm{C}$ equipped with TOSOH G4000 $(10 \mu \mathrm{m}, 7.8 \times 300 \mathrm{~mm})$ and G3000 $(7 \mu \mathrm{m}, 7.8 \times 300 \mathrm{~mm})$ PWXL columns in series eluted with $0.4 \mathrm{M}$ ammonium acetate buffer $\mathrm{pH}$ 4.5. Data acquisition was performed by Omnisec 5.1 software using the pullulan standard for calibration.

\subsection{Cell Culture}

HepG2 (hepatocellular cancer cell line) and A549 (lung cancer cell line) were purchased from the American Type Culture Collection (ATCC, USA). Cells were cultured at $37^{\circ} \mathrm{C}$, $5 \% \mathrm{CO}_{2}$, and humidified atmosphere using Dulbecco's modified Eagle medium (DMEM, Lonza, Switzerland) supplemented with $10 \%$ fetal bovine serum (FBS, Gibco Laboratories, USA), $100 \mathrm{U} / \mathrm{mL}$ penicillin, $100 \mu \mathrm{g} / \mathrm{mL}$ streptomycin (Gibco Laboratories), and $2 \mathrm{mM}$ L-glutamine (Gibco Laboratories) (complete medium). Juvenile fibroblasts were kindly provided by Dr. Rinner from the Medical University of Graz and were cultured at $37^{\circ} \mathrm{C}$, and $5 \% \mathrm{CO}_{2}$ in a humidified atmosphere using DMEM (Lonza, Switzerland) supplemented with 2 mM L-glutamine (Gibco Laboratories) and 10\% fetal bovine serum (FBS, Gibco Laboratories, USA).

2.5. Synthesis of 4-(4,6-Dimethoxy-1,3,5-triazin-2-yl)-4-methylmorpholinium Chloride (DMTMM) (2)

DMTMM was synthesized according to a two-step procedure as described by Cronin et al. [30] and Kunishima et al. [31] (Scheme S1, Figures S1-S4). 


\subsubsection{Synthesis of 2-chloro-4,6-dimethoxy-1,3,5-triazine (CDMT) (1)}

Briefly, methanol $(\mathrm{MeOH})(6.75 \mathrm{~mL})$, MilliQ water $(659 \mu \mathrm{L})$, and $\mathrm{Na}_{2} \mathrm{CO}_{3}(3.42 \mathrm{~g}$, $40,7 \mathrm{mmol})$ were mixed and cooled to $10-15^{\circ} \mathrm{C}$. Cyanuric chloride $(2.5 \mathrm{~g}, 13.6 \mathrm{mmol})$ was added under stirring, and the resulting mixture was warmed to $35^{\circ} \mathrm{C}$. The reaction mixture was stirred for $12 \mathrm{~h}$ until the complete disappearance of the starting material was confirmed by ${ }^{1} \mathrm{H}$ NMR analysis. Then, 5 volumes of DI water were added, and the resulting mixture was further stirred for $30 \mathrm{~min}$ at room temperature. The product was isolated by filtration, and the solid residue was washed with DI water. The final product was dried under vacuum at $30{ }^{\circ} \mathrm{C}$ to yield the intermediate CDMT $(1.279 \mathrm{~g}, 7.4 \mathrm{mmol}, 54.7 \%$ yield) that was used for the next step without further purification. Indeed, the reaction was carried out according to Cronin et al. [30], conditions that minimize the formation of side product 2,4,6-trimethoxy-1,3,5-triazine derivative (1-2\%), which would not react in the next step can be removed according to the purification procedure described below.

${ }^{1} \mathrm{H} \mathrm{NMR}\left(400 \mathrm{MHz}, \mathrm{CDCl}_{3}, \delta\right): 4.07\left(\mathrm{~s}, 6 \mathrm{H}, \mathrm{OCH}_{3}\right)$.

${ }^{13} \mathrm{C}\left\{{ }^{1} \mathrm{H}\right\} \mathrm{NMR}\left(100 \mathrm{MHz}, \mathrm{CDCl}_{3}, \delta\right): 56.20\left(2 \mathrm{C}, \mathrm{OCH}_{3}\right), 172.24$ (2C, CO), 172.91 (1C, CCl).

2.5.2. Synthesis of 4-(4,6-Dimethoxy-1,3,5-triazin-2-yl)-4-methylmorpholinium Chloride (DMTMM) (2)

CDMT (750 mg, $4.28 \mathrm{mmol}$ ) and N-methylmorpholine (NMM) $(433 \mathrm{mg}, 4.28 \mathrm{mmol}$, $471 \mu \mathrm{L})$ were dissolved in tetrahydrofuran (THF) $(17 \mathrm{~mL}$ ) and left under stirring at room temperature for $30 \mathrm{~min}$. The formation of a white precipitate was observed that was collected by filtration, rinsed with THF, and dried under reduced pressure to yield a white powder (850 mg, $3.07 \mathrm{mmol}, 71.93 \%)$.

${ }^{1} \mathrm{H}$ NMR $\left(400 \mathrm{MHz}, \mathrm{MeOH}-d_{4}, \delta\right): 3.54\left(s, 3 \mathrm{H}, \mathrm{NCH}_{3}\right), 3.76-3.95\left(m, 4 \mathrm{H}, \mathrm{NCH}_{2} \mathrm{CH}_{2} \mathrm{O}\right), 4.02-$ $4.12\left(m, 2 \mathrm{H}, \mathrm{NCH}_{2} \mathrm{CH}_{2} \mathrm{O}\right), 4.18\left(\mathrm{~s}, 6 \mathrm{H}, \mathrm{OCH}_{3}\right), 4.49-4.60\left(m, 2 \mathrm{H}, \mathrm{NCH}_{2} \mathrm{CH}_{2} \mathrm{O}\right), 4.79-4.85(m$, $2 \mathrm{H}, \mathrm{NCH}_{2} \mathrm{CH}_{2} \mathrm{O}$ ).

$\left.{ }^{13} \mathrm{C}^{1}{ }^{1} \mathrm{H}\right\} \mathrm{NMR}\left(100 \mathrm{MHz}, \mathrm{MeOH}-d_{4}, \delta\right): 56.45\left(1 \mathrm{C}, \mathrm{NCH}_{3}\right), 57.55\left(2 \mathrm{C}, \mathrm{OCH}_{3}\right), 61.41(2 \mathrm{C}$, $\left.\mathrm{NCH}_{2} \mathrm{CH}_{2} \mathrm{O}\right), 63.20\left(2 \mathrm{C}, \mathrm{NCH}_{2} \mathrm{CH}_{2} \mathrm{O}\right), 171.93\left(1 \mathrm{C}, \mathrm{NCN}^{+}\right), 175.48\left(2 \mathrm{C}, \mathrm{NCOCH}_{3}\right)$.

\subsection{Synthesis of 4-cyano-4-(ethylsulfanylthiocarbonylsulfanyl)pentanoic Acid RAFT Agent (4)}

The synthesis of the RAFT agent 4-cyano-4-(ethylsulfanylthiocarbonylsulfanyl)pentanoic acid was performed in a two-step reaction according to the procedure described by Truong et al. [32] (Scheme S2, Figures S5 and S6).

\subsubsection{Synthesis of bis(ethylsulfanylthiocarbonyl)disulfide (3)}

In a 2-neck round bottom flask, $9.6 \mathrm{~mL}$ of a $0.5 \mathrm{mg} / \mathrm{mL} \mathrm{NaOH}$ aqueous solution $(0.12 \mathrm{~mol})$ was added dropwise over $5 \mathrm{~min}$ under nitrogen atmosphere to a stirred solution of ethanethiol $(7.4 \mathrm{~mL}, 0.10 \mathrm{~mol})$ in a mixture of water/acetone $20: 5(25 \mathrm{~mL})$ cooled on ice. Carbon disulfide $\left(\mathrm{CS}_{2}\right)(8.37 \mathrm{~g}, 0.11 \mathrm{~mol})$ was added to the reaction with cooling and constant stirring over a 1-h period, and the reaction was stirred until total consumption of $\mathrm{CS}_{2}$, which was checked by extended range ${ }^{13} \mathrm{C}$ NMR. Potassium ferrocyanide (36.21 g, $0.11 \mathrm{~mol}$ ) was immediately added and stirred for $30 \mathrm{~min}$ at $0{ }^{\circ} \mathrm{C}$ until the solution turned dark yellow, and a precipitate was observed. The reaction mixture was extracted with DCM, and the organic layer was then washed twice with aqueous saturated $\mathrm{NaHCO}_{3}(2 \times 30 \mathrm{~mL})$, twice with distilled water $(2 \times 30 \mathrm{~mL})$, and dried with $\mathrm{MgSO}_{4}$. After filtration, the solvent was removed under reduced pressure to yield bis(ethylsulfanylthiocarbonyl)disulfide as a crude orange oil residue $(9.5 \mathrm{~g}, 0.035 \mathrm{~mol}, 70 \%$ yield $)$. The crude product was used for the next step reaction without further purification.

${ }^{1} \mathrm{H}$ NMR (400 MHz, $\left.\mathrm{CDCl}_{3}, \delta\right): 1.36\left(t, 3 \mathrm{H}, J=7.5 \mathrm{~Hz}, \mathrm{CH}_{3}\right), 3.31\left(q, 2 \mathrm{H}, J=7.5 \mathrm{~Hz}, \mathrm{CH}_{2}\right)$.

${ }^{13} \mathrm{C}\left\{{ }^{1} \mathrm{H}\right\} \mathrm{NMR}\left(100 \mathrm{MHz}, \mathrm{CDCl}_{3}, \delta\right): 12.5\left(1 \mathrm{C}, \mathrm{CH}_{3}\right), 32.7\left(1 \mathrm{C}, \mathrm{CH}_{2}\right), 221.4(1 \mathrm{C},-\mathrm{SC}(\mathrm{S}) \mathrm{S}-)$. 
2.6.2. Synthesis of 4-cyano-4-(ethylsulfanylthiocarbonylsulfanyl)pentanoic Acid (4)

Five grams of crude bis(ethylsulfanylthiocarbonyl)disulfide $(0.021 \mathrm{~mol})$ was dissolved in ethanol, and 4,4'-azobis(cyanopentanoic acid) $(8.30 \mathrm{~g}, 0.029 \mathrm{~mol})$ was added. The reaction mixture was degassed by nitrogen bubbling for $10 \mathrm{~min}$, heated at $60^{\circ} \mathrm{C}$, and left under stirring at this temperature overnight. The reaction was then cooled to room temperature, and the solvent was evaporated under reduced pressure. The final product was purified by column chromatography on $\mathrm{SiO}_{2}$ and was eluted using a gradient of DCM/EtOAc from 10:0 to 9:1. Two column purifications were necessary to remove traces of starting material. The solvent was removed under reduced pressure to yield the RAFT agent 4-cyano-4-(ethylsulfanylthiocarbonylsulfanyl)pentanoic acid ( $1.8 \mathrm{~g}, 8 \mathrm{mmol}, 38 \%$ yield) as a yellow powder.

${ }^{1} \mathrm{H}$ NMR (400 MHz, $\left.\mathrm{CDCl}_{3}, 8\right): 1.36\left(t, 3 \mathrm{H}, J=7.4, \mathrm{~Hz} \mathrm{CH}_{3} \mathrm{CH}_{2}\right), 1.89\left(s, 3 \mathrm{H}, \mathrm{CH}_{3} \mathrm{C}\right), 2.33-$ $2.60\left(m, 2 \mathrm{H}, \mathrm{CH}_{2} \mathrm{CH}_{2} \mathrm{COOH}\right), 2.64-2.73\left(m, 2 \mathrm{H}, \mathrm{CH}_{2} \mathrm{CH}_{2} \mathrm{COOH}\right), 3.33\left(q, 2 \mathrm{H}, J=7.4 \mathrm{~Hz}, \mathrm{CH}_{2}\right)$.

${ }^{13} \mathrm{C}\left\{{ }^{1} \mathrm{H}\right\} \mathrm{NMR}\left(100 \mathrm{MHz}, \mathrm{CDCl}_{3}, \delta\right): 12.85\left(1 \mathrm{C}, \mathrm{CH}_{3} \mathrm{CH}_{2}\right), 25.02\left(1 \mathrm{C}, \mathrm{CH}_{3} \mathrm{C}\right), 29.48$ (1C, $\left.\mathrm{CH}_{2} \mathrm{CH}_{2} \mathrm{COOH}\right), 31.55\left(1 \mathrm{C}, \mathrm{CH}_{2} \mathrm{CH}_{2} \mathrm{COOH}\right), 33.69\left(1 \mathrm{C}, \mathrm{CH}_{3} \mathrm{CH}_{2}\right), 46.37\left(1 \mathrm{C}, \mathrm{CH}_{3} \mathrm{CCN}\right)$, $\delta 119.03(1 \mathrm{C}, \mathrm{CN}), 176.18\left(1 \mathrm{C}, \mathrm{CH}_{2} \mathrm{COOH}\right), 216.77$ (1C, SC(S)S).

ESI-TOF $m / z$ : $[\mathrm{M}-\mathrm{Na}]^{+}$calcd for $\left[\mathrm{C}_{9} \mathrm{H}_{13} \mathrm{NO}_{2} \mathrm{~S}_{3} \mathrm{Na}\right]^{+}$286.0001, found $285.9994(100.0 \%)$.

\subsection{Synthesis of $O-\beta$-D-galactopyranosyloxyethyl Acrylamide (6)}

The synthesis of $\alpha$-D-galactopyranosyloxyethyl acrylamide was performed according to the procedure described by Martinez-Pomares et al. [33] (Scheme S3, Figures S7 and S8).

\subsubsection{Synthesis of 2,3,4,6-O-tetraacetyl-D-galactopyranosyloxyethyl Acrylamide (5)}

$\beta$-D-Galactose pentaacetate $(25 \mathrm{~g}, 64.10 \mathrm{mmol})$ was dissolved in $\mathrm{CH}_{2} \mathrm{Cl}_{2}(50 \mathrm{~mL})$, and $\mathrm{N}$-hydroxyethyl acrylamide $(11.05 \mathrm{~g}, 96 \mathrm{mmol}, 10 \mathrm{~mL})$ was added under stirring. $\mathrm{BF}_{3} \mathrm{Et}_{2} \mathrm{O}$ $(13.65 \mathrm{~g}, 96 \mathrm{mmol}, 12 \mathrm{~mL})$ was added dropwise over $1 \mathrm{~h}$ to the reaction mixture pre-cooled on an ice bath. The reaction was left under stirring at room temperature for $48 \mathrm{~h}$. At scheduled times (every $24 \mathrm{~h}$ ), the progress of the reaction was monitored by ${ }^{13} \mathrm{C} N M R$ analysis in DMSO- $d_{6}$ of samples withdrawn from the reaction solution by checking the shift of the anomeric carbon from 89 to 100. At full conversion, the reaction mixture was poured into saturated aqueous $\mathrm{NaHCO}_{3}$. Finally, the organic phase was washed with DI water $(2 \times 125 \mathrm{~mL})$, dried over $\mathrm{MgSO}_{4}$, and the solvent evaporated under reduced pressure. The crude product was purified by flash chromatography $(\Phi=5 \mathrm{~cm}, \mathrm{~h}=15 \mathrm{~cm})$ (Silica gel $60 \AA$, particle size $35-70 \mu \mathrm{m}$, gradient elution from $100 \% \mathrm{Et}_{2} \mathrm{O}$ to $\left.100 \% \mathrm{EtOAc}\right)$. Fractions were analyzed by TLC ( $100 \% \mathrm{Et}_{2} \mathrm{O}$ as eluent), and the appropriate were concentrated to yield compound 2,3,4,6-O-tetraacetyl-D-galactopyranosyloxyethyl acrylamide as white crystals (6.623 $\mathrm{g}, 14.86 \mathrm{mmol}, 23.2 \%$ yield).

${ }^{1} \mathrm{H}$ NMR $\left(400 \mathrm{MHz}\right.$, DMSO- $\left.d_{6}, \delta\right): 1.91\left(s, 3 \mathrm{H}, \mathrm{CH}_{3}\right), 1.99\left(s, 3 \mathrm{H}, \mathrm{CH}_{3}\right), 2.01\left(s, 3 \mathrm{H}, \mathrm{CH}_{3}\right), 2.12$ $\left(s, 3 \mathrm{H}, \mathrm{CH}_{3}\right), 3.29\left(d t, J=7.0,3.5 \mathrm{~Hz}, 2 \mathrm{H}, \mathrm{CH}_{2} \mathrm{NH}\right), 3.54-3.66(m, 1 \mathrm{H}, \mathrm{CHCHH}), 3.69-3.80$ $(m, 1 \mathrm{H}, \mathrm{CHCHH}), 3.97-4.08\left(m, 2 \mathrm{H}, \mathrm{CH}_{2} \mathrm{CH}_{2} \mathrm{NH}\right), 4.20(d d, J=7.0,6.2 \mathrm{~Hz}, 1 \mathrm{H}, \mathrm{CH}), 4.73$ $(d, J=1.3 \mathrm{~Hz}, 1 \mathrm{H}, \mathrm{CH}$ anomeric), $4.94(d d, J=9.9 \mathrm{~Hz}, 1 \mathrm{H}, \mathrm{CH}), 5.15(d d, J=3.5,1.6 \mathrm{~Hz}, 1 \mathrm{H}$, CH) $5.26(d, J=9.9,3.5 \mathrm{~Hz}, 1 \mathrm{H}, \mathrm{CH}), 5.58(d d, J=10.1,2.3 \mathrm{~Hz}, 1 \mathrm{H}, \mathrm{CH}=\mathrm{CHH}), 6.08(d d$, $J=17.1,2.3 \mathrm{~Hz}, 1 \mathrm{H}, \mathrm{CH}=\mathrm{CHH}), 6.23\left(d d, J=17.1,10.1 \mathrm{~Hz}, 1 \mathrm{H}, \mathrm{CH}=\mathrm{CH}_{2}\right), 8.12(t, J=5.4 \mathrm{~Hz}$, $1 \mathrm{H}, \mathrm{NH})$.

${ }^{13} \mathrm{C}\left\{{ }^{1} \mathrm{H}\right\} \mathrm{NMR}\left(100 \mathrm{MHz}, \mathrm{DMSO}-d_{6}, \delta\right): 20.79\left(1 \mathrm{C}, \mathrm{CH}_{3}\right), 20.86\left(1 \mathrm{C}, \mathrm{CH}_{3}\right), 20.95\left(2 \mathrm{C}, \mathrm{CH}_{3}\right)$, $39.08\left(1 \mathrm{C}, \mathrm{CH}_{2} \mathrm{NH}\right), 61.67\left(1 \mathrm{C}, \mathrm{CHCH}_{2}\right), 67.83\left(1 \mathrm{C}, \mathrm{CH}_{2} \mathrm{CH}_{2} \mathrm{NH}\right), 68.25(1 \mathrm{C}, \mathrm{CHOC}=\mathrm{O}), 69.02$ $(1 \mathrm{C}, \mathrm{CHOC}=\mathrm{O}), 70.46(1 \mathrm{C}, \mathrm{CHOC}=\mathrm{O}), 70.71\left(1 \mathrm{C}, \mathrm{CHCH}_{2} \mathrm{OC}=\mathrm{O}\right), 100.34$ (1C, $\mathrm{C}$ anomeric), $125.50\left(1 \mathrm{C}, \mathrm{CH}=\mathrm{CH}_{2}\right), 132.32\left(1 \mathrm{C}, \mathrm{CH}=\mathrm{CH}_{2}\right), 165.12(1 \mathrm{C}, \mathrm{NHC}=\mathrm{O}), 169.61\left(1 \mathrm{C}, \mathrm{C}=\mathrm{OCH}_{3}\right)$, $169.97\left(1 \mathrm{C}, \mathrm{C}=\mathrm{OCH}_{3}\right), 170.37\left(1 \mathrm{C}, \mathrm{C}=\mathrm{OCH}_{3}\right), 170.40\left(1 \mathrm{C}, \mathrm{C}=\mathrm{OCH}_{3}\right)$.

ESI-TOF $m / z$ : $[\mathrm{M}-\mathrm{H}]^{+}$calcd for $\left[\mathrm{C}_{19} \mathrm{H}_{28} \mathrm{NO}_{11}\right]^{+} 446.428$; found 446.1736 . 
FT-IR $v: 3262,3063,2882,1752,1616,1365,1217,1172,1134,1093,1045,934,901,812,737$, $601 \mathrm{~cm}^{-1}$.

2.7.2. Deprotection of 2,3,4,6-O-D-galactopyranosyloxyethyl Acrylamide to Give D-galactopyrano- Syloxyethyl Acrylamide (6)

2,3,4,6-O-tetraacetyl-D-galactopyranosyloxyethyl acrylamide (6.623 g, $14.86 \mathrm{mmol}$ ) was dissolved in $73 \mathrm{~mL}$ of a $\mathrm{KOH}(83 \mathrm{mg}$, $1.486 \mathrm{mmol})$ methanolic solution. The mixture was left under stirring at room temperature for $48 \mathrm{~h}$ and passed through a short pad of silica (silicagel $60 \AA$, particle size $35-70 \mu \mathrm{m}$, eluent $100 \% \mathrm{CH}_{3} \mathrm{OH}$ ). The organic phase was concentrated under pressure to isolate the D-galactopyranosyloxyethyl acrylamide (2) (3.9 $\mathrm{g}, 14.06 \mathrm{mmol}$, $95.28 \%$ yield).

${ }^{1} \mathrm{H}$ NMR $\left(400 \mathrm{MHz}\right.$, DMSO- $\left.d_{6}, \delta\right): 3.26-3.34\left(m, 5 \mathrm{H}, \mathrm{CHOH}, \mathrm{CH}_{2} \mathrm{CH}_{2} \mathrm{NH}, \mathrm{CH}_{2} \mathrm{NH}\right)$, 3.44-3.57 (m, 3H, $\left.\mathrm{CHOH}, \mathrm{CH}_{2} \mathrm{OH}\right), 3.62(\mathrm{~m}, 1 \mathrm{H}, \mathrm{CHOH}), 3.75(d t, 1 \mathrm{H}, J=10.4,5.8 \mathrm{~Hz}$, $\left.\mathrm{CHCH}_{2} \mathrm{OH}\right), 4.09(d, 1 \mathrm{H}, J=7.1 \mathrm{~Hz}, \mathrm{CH}$ anomeric), $4.39(b s, 1 \mathrm{H}, J=3.0 \mathrm{~Hz}, \mathrm{OH}),, 4.64(b s$, $1 \mathrm{H}, \mathrm{OH}) 4.51(b s, 1 \mathrm{H}, \mathrm{OH}), 4.86(b s, 1 \mathrm{H}, \mathrm{OH}), 5.58(d d, J=10.1,2.2 \mathrm{~Hz}, 1 \mathrm{H}, \mathrm{CH}=\mathrm{CHH})$, $6.08(d d, J=17.1,2.2 \mathrm{~Hz}, 1 \mathrm{H}, \mathrm{CH}=\mathrm{CHH}), 6.24\left(d d, J=17.1,10.1 \mathrm{~Hz}, 1 \mathrm{H}, \mathrm{CH}=\mathrm{CH}_{2}\right), 810(t$, $J=5.4 \mathrm{~Hz}, 1 \mathrm{H}, \mathrm{NH})$.

${ }^{13} \mathrm{C}\left\{{ }^{1} \mathrm{H}\right\} \mathrm{NMR}\left(100 \mathrm{MHz}, \mathrm{DMSO}-d_{6}, \delta\right): \delta 48.62\left(1 \mathrm{C}, \mathrm{CH}_{2} \mathrm{NH}\right), 60.51\left(1 \mathrm{C}, \mathrm{CH}_{2} \mathrm{OH}\right), 67.73$ $\left(1 \mathrm{C}, \mathrm{CH}_{2} \mathrm{CH}_{2} \mathrm{NH}\right), 6816(1 \mathrm{C}, \mathrm{CHOH}), 70.58(1 \mathrm{C}, \mathrm{CHOH}), 73.31(1 \mathrm{C}, \mathrm{CHOH}), 75.30(1 \mathrm{C}$, $\left.\mathrm{CHCH}_{2} \mathrm{OH}\right), 103.78$ (1C, $\mathrm{C}$ anomeric), $125.21\left(1 \mathrm{C}, \mathrm{CH}=\mathrm{CH}_{2}\right), 131.70\left(1 \mathrm{C}, \mathrm{CH}=\mathrm{CH}_{2}\right), 164.70$ $(1 \mathrm{C}, \mathrm{NHCO})$.

ESI-TOF m/z: [M-Na] $]^{+}$calcd for $\left[\mathrm{C}_{11} \mathrm{H}_{19} \mathrm{NO}_{7} \mathrm{Na}\right]^{+}$300.2597; found 300.1092 .

FT-IR $v$ 3324, 2933, 2344, 1647, 1559, 1250, 1076, 893, $779 \mathrm{~cm}^{-1}$.

\subsection{Synthesis of Agmatine Acrylamide (Agm) (7)}

Agmatine Acrylamide (Agm) was synthesized according to the procedure described by Algotsson M. et al. [34] with slight modifications (Scheme S4, Figures S9 and S10).

Agmatine Sulfate $(2 \mathrm{~g}, 8.76 \mathrm{mmol})$ was dissolved in a $30 \mathrm{mM}$ solution of $\mathrm{K}_{2} \mathrm{CO}_{3}$ $(16 \mathrm{~mL}, 0.48 \mathrm{mmol})$ under stirring, and the reaction mixture was cooled at $0{ }^{\circ} \mathrm{C}$ in an ice bath. Acryloyl chloride $(7.12 \mathrm{~mL}, 87.6 \mathrm{mmol})$ was added in $350 \mu \mathrm{L}$ aliquots. The $\mathrm{pH}$ of the solution was monitored and maintained in the range of 8 to 9 by the addition of the required amount of $2 \mathrm{M} \mathrm{NaOH}$ solution. The reaction was monitored by TLC using $100 \%$ methanol $(\mathrm{MeOH})$ as eluent until the disappearance of the violet spot visualized by ninhydrin staining $(0.2 \%$ w/v ethanolic solution). Subsequently, the mixture was acidified to $\mathrm{pH} 2$ with $1 \mathrm{M} \mathrm{HCl}$. The side-product acrylic acid was removed by extraction with $10 \times 15 \mathrm{~mL}$ of chloroform $\left(\mathrm{CHCl}_{3}\right)$, and the purification was monitored by TLC using $100 \%$ methanol $(\mathrm{MeOH})$ until the complete disappearance of the acrylic acid spot in the organic phase. The aqueous phase was collected, neutralized with $1 \mathrm{M} \mathrm{NaOH}$, and traces of solvent were removed under vacuum. The aqueous phase containing the product was freeze-dried, re-dissolved in $\mathrm{MeOH}$, and passed through a short pad of silica to remove salts (Silica gel $60 \AA$, particles size 35-70 $\mu \mathrm{m}$ ). The solvent was removed under reduced pressure, and the pure product was re-dissolved in DI water and recovered by lyophilization. Acryloyl agmatine was obtained as a white powder $(1.2 \mathrm{~g}, 6.5 \mathrm{mmol}, 74.2 \%$ yield $)$.

${ }^{1} \mathrm{H}$ NMR $\left(400 \mathrm{MHz}, \mathrm{D}_{2} \mathrm{O}, \delta\right): 1.59\left(m, 4 \mathrm{H}, \mathrm{NHCH}_{2} \mathrm{CH}_{2} \mathrm{CH}_{2} \mathrm{CH}_{2}\right), 3.19-3.28(m, 4 \mathrm{H}$, $\left.\mathrm{NHCH}_{2} \mathrm{CH}_{2} \mathrm{CH}_{2} \mathrm{CH}_{2} \mathrm{NH}\right), 5.74(d d, J=9.8,1.8 \mathrm{~Hz}, 1 \mathrm{H} \mathrm{CHH}=\mathrm{CH}), \delta 6.16(d d, J=17.1$, $1.8 \mathrm{~Hz}, 1 \mathrm{H}, \mathrm{CHH}=\mathrm{CH}) ; 6.25\left(d d, J=17.1,9.8 \mathrm{~Hz}, 1 \mathrm{H}, \mathrm{CH}_{2}=\mathrm{CH}\right)$.

${ }^{13} \mathrm{C}\left\{{ }^{1} \mathrm{H}\right\}$-NMR (100 MHz, $\left.\mathrm{D}_{2} \mathrm{O}, \delta\right): 25.30\left(1 \mathrm{C}, \mathrm{NHCH}_{2} \mathrm{CH}_{2} \mathrm{CH}_{2} \mathrm{CH}_{2} \mathrm{NH}\right), 25.56$ (1C, $\left.\mathrm{NHCH}_{2} \mathrm{CH}_{2} \mathrm{CH}_{2} \mathrm{CH}_{2} \mathrm{NH}\right), 38.83\left(1 \mathrm{C}, \mathrm{NHCH}_{2}\right), 40.86\left(1 \mathrm{C}, \mathrm{CH}_{2} \mathrm{NH}\right), 127.21\left(1 \mathrm{C}, \mathrm{CH}_{2}=\mathrm{CH}\right)$, $130.04\left(1 \mathrm{C}, \mathrm{CH}_{2}=\mathrm{CH}\right), 156.74\left(1 \mathrm{C}, \mathrm{NH}_{2} \mathrm{CNH}\right), 168.56(1 \mathrm{C}, \mathrm{NHC}=\mathrm{O})$.

ESI-TOF $m / z$ : $[\mathrm{M}-\mathrm{H}]^{+}$calcd for $\left[\mathrm{C}_{8} \mathrm{H}_{17} \mathrm{~N}_{4} \mathrm{O}\right]^{+} 185.13$; found 185.140 .

FT-IR $v=3314,2875,1648,1605,1264,1087,610,553 \mathrm{~cm}^{-1}$. 


\subsection{Synthesis of $\mathrm{Gal}_{32}-\mathrm{b}-\mathrm{Agm}_{29}$ Cationic Diblock Copolymer (9)}

$\mathrm{Gal}_{32}-b-\mathrm{Agm}_{29}$ copolymer was synthesized by Fast RAFT polymerization according to the procedure reported by Gody et al. [35] and modified by Mastrotto et al. [33,36].

Briefly, D-Galactopyranosyloxyethyl acrylamide (Gal, $157 \mathrm{mg}, 0.57 \mathrm{mmol}$ ) was dissolved in MilliQ water $(157 \mu \mathrm{L})$, placed in a tube equipped with a magnetic follower, and RAFT agent ( $4.7 \mathrm{mg}, 17.7 \mu \mathrm{mol} ; 31.7 \mu \mathrm{L}$ of $150 \mathrm{mg} / \mathrm{mL}$ stock solution in dioxane) was added. The tube was then placed in an ice bath, and freshly prepared VA-044 $(0.11 \mathrm{mg}$, $0.36 \mu \mathrm{mol} ; 11.46 \mu \mathrm{L}$ of $10 \mathrm{mg} / \mathrm{mL}$ stock solution in MilliQ water) was added to the reaction mixture under stirring. The tube was sealed with a rubber septum and deoxygenated by gentle Argon bubbling for $10 \mathrm{~min}$. The polymerization was started by placing the tube in an oil bath preheated at $60{ }^{\circ} \mathrm{C}$. The reaction was monitored by ${ }^{1} \mathrm{H}$ NMR in DMSO- $d_{6}$, analyzing samples withdrawn from the polymerization mixture at $2 \mathrm{~h}$. Sequential addition of VA-044 solution was made until the conversion percentage was $>90 \%$. The generated macro-CTA Gal 32 (8) was finally characterized by ${ }^{1} \mathrm{H}$ NMR.

${ }^{1} \mathrm{H}$ NMR (400 MHz, DMSO- $\left.d_{6}, \delta, \mathrm{ppm}\right): 7.51$ ppm $(b r, 1 \mathrm{H}, \mathrm{NH}), 4.44 \mathrm{ppm}(d, 1 \mathrm{H}, \mathrm{O}-\mathrm{CH}$ anomeric), 4.16-5.05 ppm ( $m, 4 \mathrm{H}, \mathrm{C}-\mathrm{OH}$ sugar $), 0.75-2.13 \mathrm{ppm}\left(m, 3 \mathrm{H}, \mathrm{CHCH}_{2}\right.$ polymer backbone).

Conversion: $100 \% ; M_{\mathrm{n}, \mathrm{th}}=9.1 \mathrm{kDa} ; D P=32$.

Agmatine acrylamide (104.5 mg, $0.567 \mathrm{mmol})$ was dissolved in MilliQ water $(227 \mu \mathrm{L})$ in a separate tube and then transferred to the reaction vessel (theoretical molar ratio Gal/Agm 1:1). The reaction vessel was placed in an ice bath and a freshly prepared VA-044 initiator $(0.11 \mathrm{mg}, 0.36 \mu \mathrm{mol} ; 11.46 \mu \mathrm{L}$ of a $10 \mathrm{mg} / \mathrm{mL}$ stock solution in MilliQ water) was added to the reaction mixture under stirring. The reaction mixture was degassed by Argon bubbling for $10 \mathrm{~min}$. The polymerization was started by placing the tube in an oil bath preheated at $60{ }^{\circ} \mathrm{C}$. After $2 \mathrm{~h}$, the conversion was monitored by ${ }^{1} \mathrm{H}$ NMR in DMSO- $d_{6}$ on a sample withdrawn from the reaction vessel, and the polymerization was considered complete when Agm conversion was $>80 \%$; otherwise, a second addition of the VA-044 initiator was made. The polymer was then dialyzed against MilliQ water for $48 \mathrm{~h}$ using a $3.5 \mathrm{kDa}$ MWCO dialysis membrane to remove the unreacted monomers. The product was freeze-dried, and the copolymer $\mathrm{Gal}_{32}-b-\mathrm{Agm}_{29}(9)(163 \mathrm{mg}, 11.2 \mu \mathrm{mol}, 65.1 \%$ yield) was recovered as a yellowish powder and analyzed by ${ }^{1} \mathrm{H}$ NMR and GPC.

${ }^{1} \mathrm{H}$ NMR (400 MHz, DMSO- $\left.d_{6}, \delta, \mathrm{ppm}\right): 6.78-8.42 \mathrm{ppm}(b m, 5 \mathrm{H}, \mathrm{NH}$ galactose, $\mathrm{NH}$ agmatine, $\mathrm{NH}$ guanidyl group), $4.44 \mathrm{ppm}(d, 1 \mathrm{H}, \mathrm{O}-\mathrm{CH}$ anomeric), 4.16-5.05 ppm $(\mathrm{m}$, $4 \mathrm{H}, \mathrm{C}-\mathrm{OH}$ sugar $), 0.66-2.33 \mathrm{ppm}\left(\mathrm{bm}, 10 \mathrm{H}, \mathrm{CHCH}_{2}\right.$ polymer backbone, $\mathrm{N}-\mathrm{CH}_{2}-\mathrm{CH}_{2}-\mathrm{CH}_{2}-$ $\mathrm{CH}_{2}$ agmatine).

Conversion: $90 \% ; M_{n, t h}=14.5 \mathrm{kDa} ; D P=61 ; M_{n(\mathrm{GPC}, \text { aqueous })}=21.9 \mathrm{kDa} ; \bigoplus_{(\mathrm{GPC}, \text { aqueous })}=1.4$.

$\mathrm{Gal}_{255}$ (10) homopolymer used for the competition assay was prepared as described above for $\mathrm{Gal}_{32}$ using a [Gal]:[RAFT Agent]:[VA-044] molar ratio of 260:1:0.02 and purified at the end of the polymerization reaction by dialysis against MilliQ water for $48 \mathrm{~h}$ using a $3.5 \mathrm{kDa}$ MWCO dialysis membrane to remove the unreacted monomer. The product was recovered by freeze-drying $(358.4 \mathrm{mg}, 5.05 \mathrm{mmol}, 80 \%$ yield).

Conversion: $98 \% ; M_{\mathrm{n}, \mathrm{th}}=70.9 \mathrm{kDa} ; D P=250 ; M_{n(\mathrm{GPC}, \text { aqueous })}=82.2 \mathrm{kDa}$; $Ð_{(\mathrm{GPC}, \text { aqueous })}=1.09$.

\subsection{Synthesis of Cy5 labeled $\mathrm{Gal}_{32}-b-\mathrm{Agm}_{29}\left(\mathrm{Cy} 5-\mathrm{Gal}_{32}-\mathrm{b}-\mathrm{Agm}_{29}\right)$ (11)}

$\mathrm{Gal}_{32}-b-\mathrm{Agm}_{29}(30 \mathrm{mg}, 2.07 \mu \mathrm{mol})$ was dissolved in $500 \mu \mathrm{L}$ of $50 \mathrm{mM}$ MES (2-(Nmorpholino)ethanesulfonic acid) buffer $\mathrm{pH}$ 6.5. One hundred and forty-eight microliters of a $10 \mathrm{mg} / \mathrm{mL}$ Cyanine-5-amine $\left(\mathrm{Cy} 5-\mathrm{NH}_{2}\right)$ solution in DMSO was then added, followed by $27.5 \mu \mathrm{L}$ of a freshly prepared $20 \mathrm{mg} / \mathrm{mL}$ DMTMM stock solution in MES. The reaction was left under stirring for $16 \mathrm{~h}$ at room temperature. The solution was then transferred into a $5 \mathrm{kDa}$ MWCO dialysis bag and dialyzed against $5 \mathrm{~L}$ of DI water for 3 days with at least two water exchanges per day. Finally, Cy5-Gal $32-b-\mathrm{Agm}_{29}(25.4 \mathrm{mg}, 16.8 \mu \mathrm{mol}, 81.2 \%)$ was 
isolated as a light blue powder by lyophilization. The reaction scheme is available in the Supplementary Materials (Scheme S5).

\subsection{Ad5/3-D24-ICOSL Oncolytic Adenovirus Production and Characterization}

The adenovirus vector was kindly provided by Dr. Kuryk from the NIPH-NIH (Poland) for the purpose of this experiment. The vector was generated and amplified using standard adenovirus preparation techniques [37,38]. Briefly, the Ad5 WT virus was used as a backbone for the construct (Genbank \#AY339865), and the following genetic modifications were made: (i) deletion of $24 \mathrm{bp}$ in the E1A conserved region, (ii) insertion of the inducible costimulatory ligand (ICOSL) $[39,40]$ was placed under the exogenous promoter in the E3 region. Additionally, the fiber knob was modified (AdV5/3 chimeric). Shuttle plasmids were constructed and contained modifications in E1A, E3, and fiber regions. Subsequently, the shuttle plasmids were digested with SfiI and ligated to each other. The ligation products were packed into phage lambda and infected E. coli. The selection of ampicillin and kanamycin-resistant clones was performed and was followed by DNA transfection by linearization of the cosmid DNA with PacI or SwaI. Linear cosmid was transfected into A549 helper cells. Finally, plaques were harvested, and virus identity was confirmed by restriction enzyme assays. Amplification of the virus was done in A549 cells, followed by purification on two $\mathrm{CsCl}$ gradients, dialysis against an isotonic buffer (default $=$ GTS buffer: $2.5 \%$ glycerol, $25 \mathrm{mM} \mathrm{NaCl}, 20 \mathrm{mM}$ Tris- $\mathrm{HCl}, \mathrm{pH}$ 8.0). The virus suspension was filtered through a low-protein binding $0.22 \mu \mathrm{m}$ filter. The viral particle concentration was determined by $\mathrm{OD}_{260}$-reading, and a standard $\mathrm{TCID}_{50}$ (tissue culture infectious dose 50) assay was performed to determine infectious particle titer [41,42].

\subsection{Formulation of Unlabeled and Fluorescently Labeled $\mathrm{Gal}_{32}-\mathrm{b}-\mathrm{Agm}_{29}$ Coated Ad5/3-D24-ICOSL Adenovirus}

$\mathrm{Gal}_{32}$-b-Agm 29 polymer-coated Ad5/3-D24-ICOSL oncolytic adenovirus (hereinafter referred as "PC-OV") was prepared by mixing virus particle (VP) stock solution $(1 \mu \mathrm{L}$, $\left.1 \times 10^{12} \mathrm{VP} / \mathrm{mL}\right)$ in PBS, with Gal ${ }_{32}-b$ - Agm $_{29}(1 \mu \mathrm{L}, 10 \mathrm{mg} / \mathrm{mL}$ solution) block copolymer stock solution in MilliQ water. The mixture was left at room temperature for $15 \mathrm{~min}$ and then diluted to $800 \mu \mathrm{L}$ in the appropriate buffer/medium according to the experiment performed, as described in the following paragraphs.

Fluorescently labeled VPs were prepared using a 70:30 mixture of $\mathrm{Gal}_{32}-b-\mathrm{Agm}_{29}$ and Cyanine 5-labeled $\mathrm{Gal}_{32}-b$-Agm 29 (Cy5- -Gal 32 -b-Agm 29$)$.

\subsection{Size and Zeta Potential Analyses}

The mean particle diameter, polydispersity (PDI), and zeta potential (ZP) of naked OV (uncoated copolymer Ad5-D24-ICOSL) or PC-OV were determined by Dynamic Light Scattering (DLS) using Malvern Instrument Ltd. Zetasizer Nano ZS (Malvern, UK) at a constant scattering angle of $173^{\circ}$ and $25^{\circ} \mathrm{C}$. Formulations were prepared by diluting naked OV or PC-OV suspensions prepared as described in "Formulation of unlabeled and fluorescently labeled $\mathrm{Gal}_{32}$-b-Agm 29 coated Ad5/3-D24-ICOSL adenovirus".

\subsection{Electron-Microscope Characterizations}

The morphology and structure of naked OV and PC-OC were examined by transmission electron microscopy (TEM) using the Tecnai G2 microscope (FEI). Samples, prepared as described in "Formulation of unlabeled and fluorescently labeled $\mathrm{Gal}_{32}-\mathrm{b}-\mathrm{Agm}_{29}$ coated Ad5/3-D24-ICOSL adenovirus", were deposited on a small holey carbon-coated support grid (400 mesh), and the solvent was allowed to dry at room temperature. Samples were negatively stained with $1 \% w / v$ aqueous uranyl acetate solution prior to imaging. TEM images were captured by rotating the sample from $+60^{\circ}$ to $-60^{\circ}$ and collected every $2^{\circ}$ of rotation. 
2.15. Evaluation of Expression Level of the Coxsackievirus and Adenovirus Receptor (CAR) and Desmoglein-2 (DSG2) in Hepatocellular Carcinoma and Lung Cancer Cells

CAR and DSG2 expression levels in HepG2 and A549 cells were assessed by staining with primary mouse monoclonal anti-CAR antibody (Santa Cruz Biotech, Dallas, TX, USA) and mouse monoclonal anti-DSG2 antibody (Abcam, Cambridge, UK), respectively, and subsequently with 1:2000 diluted Alexa-Fluor ${ }^{\circledR}$ 488- conjugated secondary antibody (Abcam, Cambridge, UK) for flow cytometry analysis (BD FACSCantoTM II, Franklin Lakes, NJ, USA). The experiment was performed in duplicate.

\subsection{Cell Cytotoxicity Studies}

HepG2 and A549 cancer and Juvenile fibroblast cell lines were seeded at a density of $1 \times 10^{4}$ cells/well in 96-well plates and maintained under standard growth conditions. After $24 \mathrm{~h}$, cells were treated with $100 \mu \mathrm{L}$ of cell culture medium containing (i) naked OV; (ii) $\mathrm{Gal}_{32}-b$-Agm 29 alone; (iii) PC-OV prepared as described in "Formulation of unlabeled and fluorescently labeled $\mathrm{Gal}_{32}$-b-Agm 29 coated Ad5/3-D24-ICOSL adenovirus"; (iv) OV and $\mathrm{Gal}_{32}-b-\mathrm{Agm}_{29}$ were separately added to the cell culture medium immediately before addition to the cells (hereinafter referred as $\mathrm{Gal}_{32}-b-\mathrm{Agm}_{29} / \mathrm{OV}$ mix). All samples added to the cells contained equivalent concentrations of $\mathrm{OV}\left(1.25 \times 10^{10} \mathrm{VP} / \mathrm{mL}\right)$ and $\mathrm{Gal}_{32^{-}}$ b-Agm $29(12.5 \mu \mathrm{g} / \mathrm{mL})$. After $72 \mathrm{~h}$, cell viability was assessed by MTS assay according to the manufacturer's protocol (Cell Titer 96 Aqueous One Solution Cell Proliferation Assay; Promega, Nacka, Sweden) using a 96-wells plate spectrophotometer Varioskan Flash Multimode Reader (Thermo Scientific) set at $\lambda=490 \mathrm{~nm}$. The absorbance value for untreated cells was set as $100 \%$ viability (control), and the viability of treated cells was expressed as a percentage of the absorbance with respect to the absorbance value of the control. Three independent experiments were performed in triplicate for each condition.

\subsection{Cell Competition Studies}

HepG2 cells were seeded in 12-well plates at a seeding density of $2 \times 10^{5}$ cells / well in $2 \mathrm{~mL}$ of complete medium and grown at $37^{\circ} \mathrm{C}, 5 \% \mathrm{CO}_{2}$, and humidified atmosphere. After $24 \mathrm{~h}$, the culture medium was replaced with $1 \mathrm{~mL}$ of $250 \mu \mathrm{g} / \mathrm{mL} \mathrm{Gal} 255$ polymer solution in cell culture medium or cell culture medium alone in the appropriate well. After $1 \mathrm{~h}$ incubation, Cy5- $\mathrm{Gal}_{32}-b$-Agm 29 coated Ad5/3-D24-ICOSL adenovirus $(2 \mu \mathrm{L}$, $0.5 \times 10^{12} \mathrm{VP} / \mathrm{mL}$ and $5 \mathrm{mg} / \mathrm{mL}$ polymer concentration) prepared as described in the paragraph "Formulation of unlabeled and fluorescently labeled $\mathrm{Gal}_{32}$-b-Agm 29 coated Ad5/3-D24-ICOSL adenovirus", was added to the appropriate wells. Control cells were added to an equal volume of cell culture medium. Cells were further incubated for $1 \mathrm{~h}$, and then the medium was discharged; cells were rinsed $3 \times 1 \mathrm{~mL} \mathrm{PBS}$ and harvested by trypsin treatment $(100 \mu \mathrm{L}, 0.03 \% w / v$ solution in PBS). Cell suspensions were immediately diluted with $200 \mu \mathrm{L}$ of PBS followed by fixation with $100 \mu \mathrm{L}$ of a $4 \% v / v$ PFA solution in PBS and stored in the dark at $4{ }^{\circ} \mathrm{C}$ until FACS analysis. Cells were analyzed by a BD FACSAriaIIITM (BD, Franklin Lakes, USA) flow cytometer, and at least $1 \times 10^{4}$ events per sample were recorded. The mean fluorescence intensity and the percentage of positive cells were detected on the Cy5 channel $\left(\lambda_{\mathrm{ex}} 633, \lambda_{\mathrm{em}} 660 / 20\right)$. Untreated cells served as negative controls. Data were analyzed with FlowJo software (v10.2, 2016, Becton, Dickinson and Company, Ashland, OR, USA).

\subsection{Determination of the Infectious Titer}

The determination of the infectivity was based on the detection of adenovirus hexon protein expression by immunostaining the infected cells. HepG2 and A549 cells were seeded at a density of $2 \times 10^{5}$ cells/well in 24-well plates and maintained under standard growth conditions. Cells were treated with $500 \mu \mathrm{L} /$ well of formulations containing naked $\mathrm{OV}, \mathrm{PC}-\mathrm{OV}$, and $\mathrm{Gal}_{32}-b-\mathrm{Agm}_{29}$ /OV mix samples prepared as described in "Cell cytotoxicity studies". After $48 \mathrm{~h}$ of incubation, supernatants were aspirated, and the cells fixed by incubation for $10 \mathrm{~min}$ with $250 \mu \mathrm{L}$ of ice-cold methanol per well. Cells were then rinsed 
with $3 \times 300 \mu \mathrm{L}$ of $1 \% w / v$ solution of bovine serum albumin in PBS and incubated with $250 \mu \mathrm{L}$ of mouse monoclonal anti-hexon primary antibodies (1:2000 dilution in a 1\% BSA in PBS) for $1 \mathrm{~h}$ at room temperature in the dark. Afterward, cells were washed $3 \times 300 \mu \mathrm{L}$ with $1 \%$ BSA in PBS and incubated with $250 \mu \mathrm{L}$ of the secondary antibody (Biotin-SP-conjugated antibody), 1:500 dilution with 1\% BSA in PBS for $1 \mathrm{~h}$ at room temperature in the dark. Finally, cells were rinsed with $1 \%$ BSA in PBS $(3 \times 300 \mu \mathrm{L})$ and incubated in the dark with $250 \mu \mathrm{L}$ of Extravidin-peroxidase (1:200 dilution in 1\% BSA in PBS) for $30 \mathrm{~min}$ at room temperature before being visualized by treatment with $250 \mu \mathrm{L}$ of $1 \times 3,3$ '-diaminobenzidine tetrahydrochloride (DAB) solution, according to the manufacturer's instructions. For each of five replicates (wells), five images of non-overlapping fields were acquired using an AMG EVO XL microscope (ThermoFisher Scientific, Waltham, MA, USA), and positive stained cells, detected as brown spots, were counted. Infectivity data are presented as the average number of positive cells per well. Three independent experiments were performed in triplicate for each condition.

\subsection{ATP and HMGB1 Release}

HepG2 and A549 cell lines were seeded in triplicate onto 96-well plates at $1 \times 10^{4}$ cells/well and infected with naked OV, $\mathrm{Gal}_{32}-b-\mathrm{Agm}_{29} / \mathrm{OV}$ mix, and PC-OV samples prepared as described in "Cell cytotoxicity studies". Three independent experiments were performed in triplicate for each condition.

\subsubsection{ATP Release}

Forty-eight hours after cell infection, supernatants were collected and analyzed with the ATP Determination Kit according to the manufacturer's protocol (Promega, Madison, WI, USA) by luminometric analysis (Varioskan Flash, ThermoFisher Scientific, Waltham, MA, USA). Untreated cells were used as control. The percentage of released ATP was calculated according to the following equation:

$$
\mathrm{ATP} \%=100-\frac{\mathrm{RLU}_{\text {sample }}}{\mathrm{RLU}_{\text {control }}} \times 100
$$

where RLU is the relative light unit.

\subsubsection{HMGB-1 Release}

Seventy-two hours after cell infection, supernatants were collected, and HMGB1 was measured with an Elisa kit according to manufacturer instructions (MBL International, Woburn, MA) and referred to a calibration curve obtained with serial dilution of standard HMGB1.

\subsubsection{Analysis of Apoptotic and Necrotic Cells}

A549 and HepG2 cells were plated into 6-well plates at a density of $2 \times 10^{5}$ cells/well. Cells were treated with naked OV, $\mathrm{Gal}_{32}-b-\mathrm{Agm}_{29}$ alone, PC-OV, and $\mathrm{Gal}_{32}-b-\mathrm{Agm}_{29} / \mathrm{OV}$ mix samples at the concentrations described in "Cell cytotoxicity studies". The amount of apoptotic and necrotic cells was measured at $24 \mathrm{~h}$ post-treatment with a TACS Annexin VFITC kit (Trevigen Inc., Gaitherburg, MD, USA) and a BD FACSCantoTM II (Franklin Lakes, NJ, USA) flow cytometer according to the manufacturer instructions. Three independent experiments were performed in triplicate for each condition.

\subsection{Statistical Analysis}

Statistical significance was analyzed by using one-way ANOVA with Tukey's Multiple Comparison test, and nonparametric Mann-Whitney test, and Student's t-test. All statistical analysis, calculations, and tests were performed using GraphPad Prism (v7.0, 2018, GraphPad Software, San Diego, CA, USA). 


\section{Results and Discussion}

Based on previous evidence demonstrating that cationic peptides can bestow cell targeting on oncolytic adenoviruses, we focused on improving the antitumor efficacy of oncoviruses (OVs) for HCC treatment by OV coating with cationic galactosylated block copolymers [43,44].

Galactose-mediated delivery of anticancer drugs to the liver exploits the asialoglycoprotein receptors (ASGPRs), which are expressed in the liver cells and not in other human cells $[45,46]$. Therefore, the OV decoration with galactosylated polymers may yield polymer/OV complexes with liver cell targeting that synergistically combined with the intrinsic ability of OVs to replicate only in tumor cells while sparing healthy cells, may result in extraordinary therapeutic selectivity for HCC. Accordingly, a galactosylated diblock copolymer, containing a poly-galactose block for HCC targeting and a positively charged poly-agmatine block for OV anchoring was designed for adenoviruses coating. The positively charged poly-agmatine was introduced in the copolymer structure to physically anchor the copolymer through electrostatic interactions to the negatively charged surface of the adenoviral capsid.

The adenovirus Ad5/3-D24-ICOSL was chosen for its great potential for oncolytic virotherapy. Indeed, Ad5/3-D24-ICOSL has modifications that can contribute to its safety [33] and efficacy against HCC. In particular, the deletion of $24 \mathrm{bp}$ in the E1A gene confers cancer cell restricted replication in tumor cells with an altered $\mathrm{Rb}$ pathway and incorporates transgene ICOSL into the $\mathrm{E} 3$ region of the adenovirus genome, which promotes systemic antitumor immunity and mediates the oncolysis of the tumor mass. OV is taken up by cells through DSG2 and CAR receptors that are expressed by a variety of tumor cells, including HCC cells. The coating with galactosylated copolymer has been designed to restrict the OV selectivity and internalization into ASGPR expressing cells, such as HCC cells.

\subsection{Synthesis of $\mathrm{Gal}_{32}-b-\mathrm{Agm}_{29}$ Cationic Block Copolymer}

The synthesis of $\mathrm{Gal}_{32}-b-\mathrm{Agm}_{29}$ block copolymer used for the OV coating was carried out by a modified version of the Reversible Addition-Fragmentation chain Transfer technique (RAFT), which allows for reducing the time required for each block synthesis $[35,36]$ and avoids intermediate purification steps (Scheme 1).
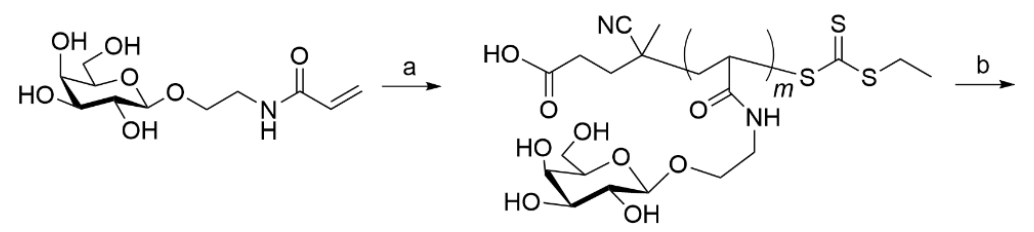

$n=29$

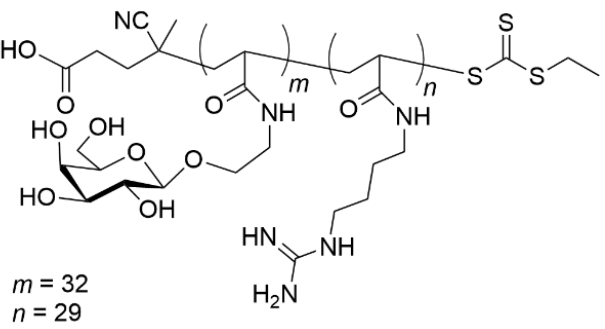

$\mathrm{Gal}_{32}-\mathrm{b}-\mathrm{Agm}_{29}(9)$

Scheme 1. Synthesis of $\mathrm{Gal}_{32}-b$-Agm 29 block copolymer (9). Reagents and conditions: (a) RAFT Agent, VA-044, water/dioxane 80:20 v/v, Ar atmosphere, $60^{\circ} \mathrm{C}, 2 \mathrm{~h}$; (b) agmatine acrylamide, VA-044, water/dioxane 80:20 v/v, Ar atmosphere, $60{ }^{\circ} \mathrm{C}, 2 \mathrm{~h}$.

O-( $\beta$-D-galactopyranosylethyl) acrylamide (Gal, compound 6) was initially polymerized to generate the first block ( $\mathrm{Gal}_{n}$, compound 8) using 1:32 RAFT agent:Gal molar ratio. Under the operative conditions, $100 \%$ monomer conversion was achieved in $2 \mathrm{~h}$ as checked by ${ }^{1} \mathrm{H}$ NMR analysis (Figure S11). The obtained macro-Chain Transfer Agent (macro-CTA) $\mathrm{Gal}_{32}$ was then chain-extended by polymerization of the positively charged monomer agmatine-acrylamide (Agm, compound 7) using 1:32 macro-CTA Gal 32 :Agm molar ratio to obtain a diblock copolymer with a similar number of monomer units per block. The polymerization yielded $90 \%$ monomer conversion, which corresponded to $\mathrm{Gal}_{32}-b$ - $\mathrm{Agm}_{29}$ (9). After purification by dialysis to remove the excess of unreacted Agm, the isolated diblock copolymer was characterized by GPC and ${ }^{1} \mathrm{H}$ NMR. The GPC chromatogram indicated 
that the copolymer had a low polydispersity index (PDI 1.4) and an $\mathrm{M}_{\mathrm{n}}$ of $21.9 \mathrm{kDa}$, which is higher than the theoretical value $\left(\mathrm{M}_{\mathrm{n}, \mathrm{th}}=14.5 \mathrm{kDa}\right)$. However, it is well documented that the estimation of molecular weight of cationic polymers can be subjected to undesired phenomena, such as ion and hydrophobic interactions or ion exclusion, which affect the analytical accuracy $[47,48]$. The ${ }^{1} \mathrm{H}$ NMR spectrum (Figures S11 and S12) and the GPC analysis (Figure S13) confirmed the copolymer Gal:Agm molar ratio and the successful purification from unreacted species.

\subsection{Oncolytic Adenoviruses Coating with $\mathrm{Gal}_{32}-\mathrm{b}-\mathrm{Agm}_{29}$}

The $\mathrm{Gal}_{32}-b-\mathrm{Agm}_{29} / \mathrm{OV}$ complexation was achieved by simple incubation of OV with diblock copolymer to yield the full coating of OVs by coulombic interactions (Figure 1A) [49]. The polymer-coated virus (PC-OV) was characterized by dynamic light scattering (DLS), zeta potential, and transmission electron microscopy (TEM) to assess the effect of the galactosylated polymer on the diameter, surface charge, and morphology of the viral particles (Figure 1B-D).

A

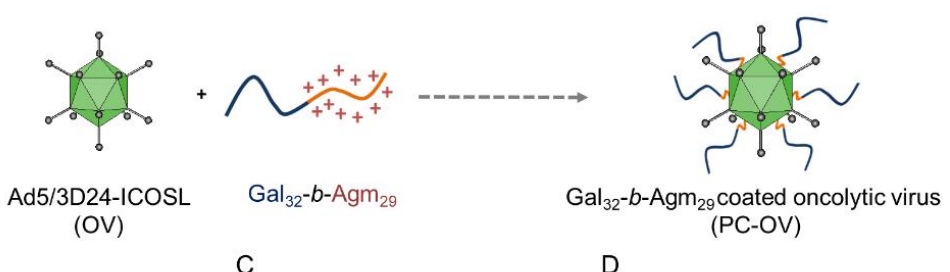

B

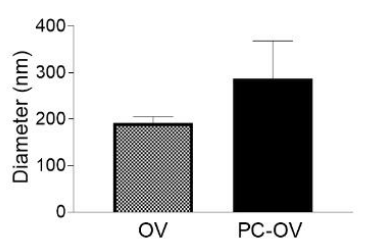

C

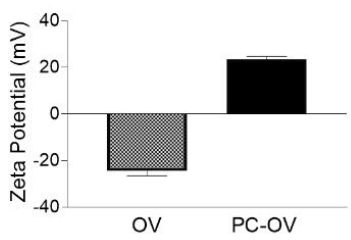

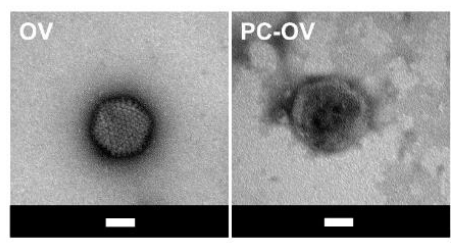

Figure 1. Surface modified oncolytic adenovirus (OV) as targeting strategies. (A) Schematic representation of the strategy to generate the OVs surface with ASPGR-targeting macromolecules. A cation block was added to the polymer to confer a positive charge that favors the interaction with the negatively charged capsid of the virus, allowing the formation of a complex (PC-OV). (B,C) Viral particles were coated with an excess of $\mathrm{Gal}_{32}-\mathrm{b}-\mathrm{Agm}_{29}$ polymer chains. After the reaction, zeta potential (B) and particle size (C) were measured. Data are reported as mean \pm SD. (D) Electron microscopy pictures of naked virus and PC-OV (scale bar $50 \mathrm{~nm}$ ).

The DLS results reported in Figure $1 \mathrm{~B}$ and zeta-potential results reported in Figure 1C confirmed the OV coating. Indeed, the polymer coating induced a shift in both OV hydrodynamic size from $191.9 \pm 13.6 \mathrm{~nm}$ with a PDI of $0.304 \pm 0.036$ for the naked OV to $287 \pm 81 \mathrm{~nm}$ with a PDI of $0.428 \pm 0.036$ for the PC-OV, and zeta potential from $-24.7 \pm 1.78 \mathrm{mV}$ for the naked $\mathrm{OV}$ to $23.3 \pm 1.29 \mathrm{mV}$ for the PC-OV. The polymer adhesion to the viral particle surface also induced a modification of the virus aspect. The TEM images reported in Figure 1D show the typical icosahedral symmetrical structure for the naked OV with an average particle diameter of $105 \mathrm{~nm}$. After coating with $\mathrm{Gal}_{32}-b-\mathrm{Agm}_{29}$, the PC-OV size was about $140 \mathrm{~nm}$, while the icosahedral aspect was hidden by the polymer shell, as already reported for polymer-coated viruses [50]. The discrepancy between the sizes obtained by DLS and TEM can be ascribed to the aggregation phenomena of a single virus during DLS analysis or to the drying process required for the TEM sample, as shown already by Nikitin et al. [51].

\subsection{Oncolytic Viruses Complexed with Galactosylated Polymers Exhibit Enhanced In Vitro Efficacy in HepG2 Hepatocarcinoma Cell Line}

Cytotoxicity studies were carried out to gain insights into the potential therapeutic value of PC-OV and its antitumor activity using the HepG2 human hepatoma cell line, 
which expresses high levels of ASGPRs that bind galactosyl moieties [52], and A549 adenocarcinomic human alveolar basal epithelial cells lacking ASGPR expression, which were used as negative control [53].

Cells were incubated with OV, PC-OV, $\mathrm{Gal}_{32}-b-\mathrm{Agm}_{29}$ alone, and a mixture of $\mathrm{Gal}_{32}-b$ $\mathrm{Agm}_{29}$ and $\mathrm{OV}\left(\mathrm{Gal}_{32}-b-\mathrm{Agm}_{29} / \mathrm{OV}\right.$ mix) separately added to the wells. To comparatively investigate the cytotoxicity and infectivity of samples, cells were incubated with equivalent $\mathrm{OV}$ and/or $\mathrm{Gal}_{32}-b-\mathrm{Agm}_{29}$ concentrations (Figure 2A-D).

A

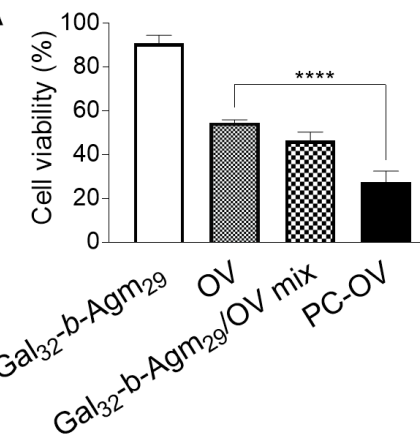

C

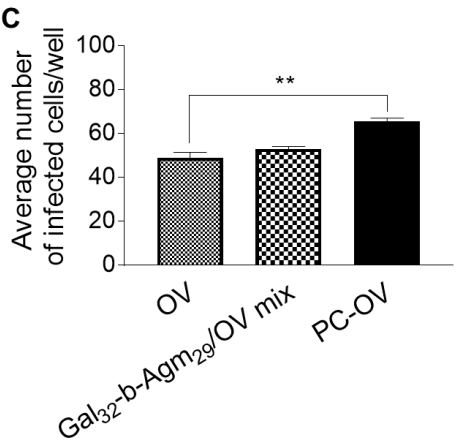

E

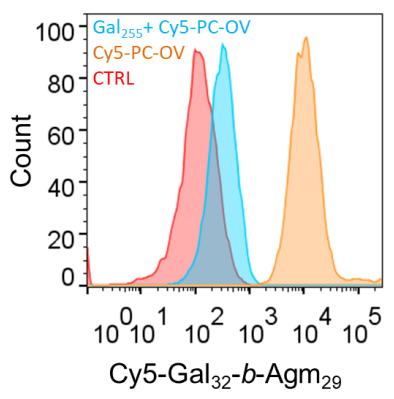

B
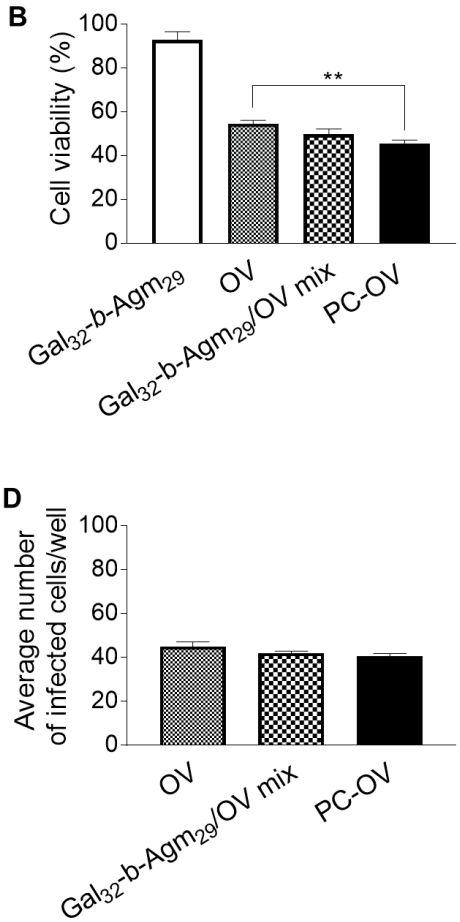

$\mathbf{F}$

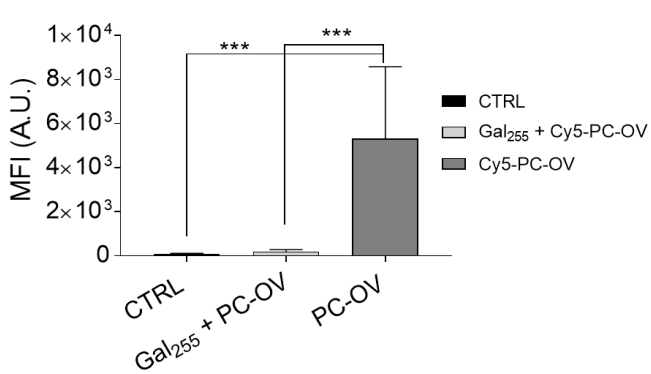

Figure 2. Cell viability, infection titer, and competition studies. (A,B) In vitro cytotoxicity of naked $\mathrm{OV}, \mathrm{Gal}_{32}-b-\mathrm{Agm}_{29}$ alone, $\mathrm{Gal}_{32}-b$-Agm $29 / \mathrm{OV}$ mix, and PC-OV was measured by a MTS cell-viability assay at day 3 post-treatment on (A) HepG2 and (B) A549 cells. Control untreated cells were used as reference ( $100 \%$ cell viability); (C,D) the infectivity of naked OV, $\mathrm{Gal}_{32}-b-\mathrm{Agm}_{29} / \mathrm{OV}$ mix, and PC-OV was assessed by ICC assay in HepG2 (C) and A459 (D) cell lines, based on visual quantification of infected cells after the staining of virus hexon protein. For every five replicates, five images of non-overlapping fields were acquired using an AMG EVO XL microscope. For infectivity comparison, the data are presented as the average number of infected cells per well. Error bars, mean $\pm \mathrm{SEM}$ : ${ }^{* *} p<0.01$; ${ }^{* * * *} p<0.0001$. (E,F) Flow cytometry histogram showing cellular uptake of Cy5-Gal $32-$ b-Agm 29 after incubation with $\mathrm{Cy}_{5}-\mathrm{Gal}_{32}-\mathrm{b}-\mathrm{Agm}_{29} / \mathrm{OV}$ complex (Cy5-PC-OV) along with control (CTRL) cells (E) and comparative median fluorescence intensity (MFI) (F) of control cells (CTRL), cells pre-incubated with $\mathrm{Gal}_{255}$ polymer followed by incubation with Cy5-PC-OV ( $\left.\mathrm{Gal}_{255}+\mathrm{Cy} 5-\mathrm{PC}-\mathrm{OV}\right)$, and cells incubated with Cy5-PC-OV only. Error bars, mean $\pm \mathrm{SD}$; ${ }^{* * *} p<0.001$. 
Figure 2A,B shows that HepG2 and A549 cell viability was above $90 \%$ when incubated with $\mathrm{Gal}_{32}-b$-Agm 29 alone for $72 \mathrm{~h}$, indicating that this copolymer is per se biocompatible, which is a prerequisite for its pharmaceutical use. On the contrary, all samples containing OV were found to induce cell death, although to a different extent.

The cytotoxicity observed with naked OV was due to the cell internalization of Ad5/3D24-ICOSL through DSG2 and CAR receptors [42], which were preliminarily found to be expressed by both HepG2 and A549 cells (Figure S14). Despite the lower expression of DSG2 and CAR receptors in A549 cells as compared to HepG2 cells, similar cytotoxicity was observed in both cell lines. This is probably due to the OV internalization by A549 cells through other receptors, including CD46 [54] or GD1a glycan [55], known to be overexpressed to a higher level by this cell line in comparison to HepG2 cells as reported by Gao et al. [56].

$\mathrm{Gal}_{32}-b$-Agm 29 /OV mix displayed slightly higher cytotoxicity than naked OV in both cell lines, suggesting that the free copolymer added to the cells may have some limited effect in promoting the OV cell penetration. It should be noted that macromolecules containing positive charges, such as guanidyl groups, favor the passive cell internalization of small molecules and colloidal systems [57].

Conversely, PC-OV exhibited higher cytotoxicity towards HepG2 than A549 cells. More importantly, in HepG2, PC-OV displayed enhanced cytotoxicity as compared to naked OV and $\mathrm{Gal}_{32}-b-\mathrm{Agm}_{29} / \mathrm{OV}$ mix (about 30\% and 20\% higher, respectively), while in A549 cells, the differences between the tested formulations were negligible (PC-OV toxicity about $9 \%$ and $4 \%$ higher as compared to $\mathrm{OV}$ and $\mathrm{Gal}_{32}-b$-Agm 29 /OV mix, respectively). The different results obtained with the two cell lines were in agreement with the high HepG2 expression of ASGPR, while A549 did not express these galactose-specific receptors, confirming that the cell uptake of PC-OV is mediated by the galactosyl coating. Cytotoxicity was additionally evaluated in the presence of increasing serum concentration (2-20\% FBS) in HepG2 cells (Figure S15), showing that the presence of serum protein has a limited impact on infectivity and therefore killing for all the tested formulations. In particular, PC-OV exhibited a negligible variation (5.6\% increase in cell viability from 2 to $20 \%$ FBS) ascribable to the stealth properties provided by the galactosyl shell.

The infectivity of the different formulations $\left(\mathrm{OV}, \mathrm{Gal}_{32}-b-\mathrm{Agm}_{29} / \mathrm{OV}\right.$ mix, PC-OV) was further investigated by an immunocytochemistry assay (ICC). Figure 2C,D shows that in HepG2 cells, the infectious titer was significantly higher in the case of PC-OV than for naked OV and $\mathrm{Gal}_{32}-b$-Agm 29 /OV mix, while in A549 cells, where ASGPRs are not expressed, all samples displayed comparable infectious titer. These results support our hypothesis that the enhanced internalization of PC-OV in comparison to OV and $\mathrm{Gal}_{32}-b-$ $\mathrm{Agm}_{29} / \mathrm{OV}$ mix is mediated by the galactosyl block of the copolymer on the viral surface which is responsible for the interaction with ASGPRs. This was further confirmed by the competition study (Figure 2E,F), where HepG2 cells were pre-incubated with $250 \mu \mathrm{g} / \mathrm{mL}$ $\mathrm{Gal}_{255}$ polymer for one hour before the addition of $\mathrm{Cy} 5-\mathrm{Gal}_{32}-b-\mathrm{Agm} 29 / \mathrm{OV}$ complex. The presence of an excess of galactose binding units displayed by $\mathrm{Gal}_{255}$ polymer and free to interact with the ASGPR almost completely abolished the Cy5-Gal $32-b$-Agm 29 /OV complex internalization by HepG2 cells.

The overall tumor cell selectivity of PC-OV was examined by using nontumor cells juvenile fibroblasts. The results reported in Figure 3 show that none of the tested samples displayed significant cytotoxicity (cell availability $>90 \%$ ), confirming the excellent biocompatibility of the copolymer and the pharmacological selectivity of OV for tumor cells.

The number of apoptotic and necrotic cells was assessed to investigate in depth the effect of the virus coating on the pharmacological performance of OV.

Figure 4A,C show that HepG2 incubation with PC-OV resulted in an increased number of apoptotic and necrotic cells $(>40 \%)$, as compared to the other samples. On the contrary, Figure 4B,D show that the number of apoptotic and necrotic A549 cells was generally low (below 20\%) in all treatments. 


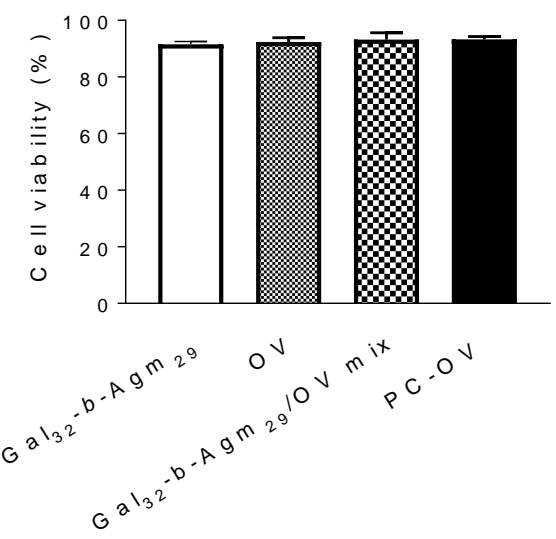

Figure 3. Cell viability on human juvenile fibroblasts. Cell viability was performed by MTS assay on juvenile fibroblasts (incubation time $96 \mathrm{~h}$ ). The absorbance was measured with a 96-wells plate spectrophotometer Varioskan Flash Multimode Reader set at the wavelength of $490 \mathrm{~nm}$.

A

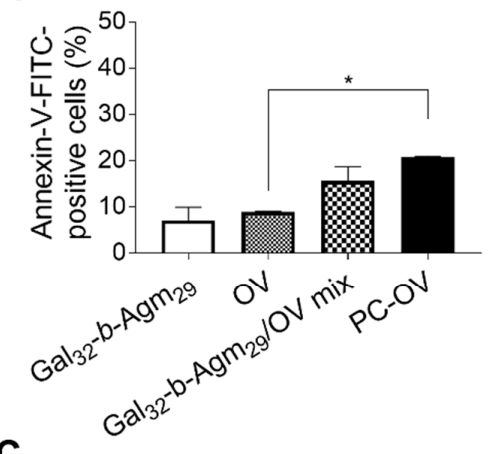

C

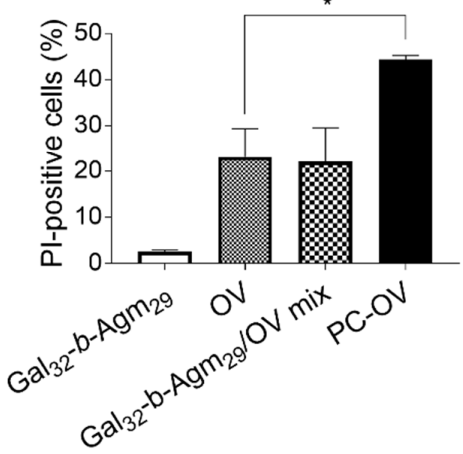

B
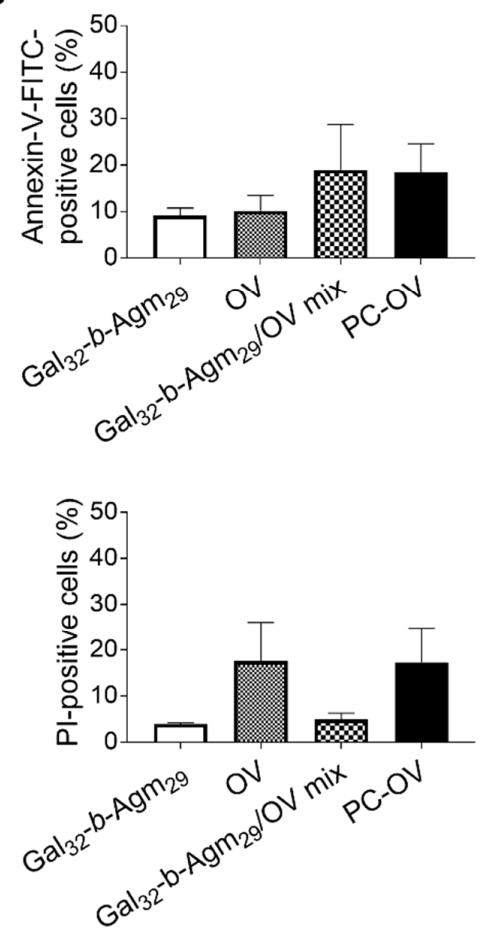

Figure 4. Induction of apoptotic and necrotic cell death. Early apoptotic (A,B) and late apoptotic/necrotic (C,D) cell death in HepG2 (A,C) and A549 (B,D) cells at 48 h post-treatment. FITClabeled Annexin-V and PI were used to detect the early apoptotic cell and the necrotic or late apoptotic cells, respectively. Representative dot plots and histogram analyses are shown in Figures S16 and S17. Error bars, mean \pm SEM; ${ }^{*} p<0.05$.

Taken together, these results suggest the potentiality of retargeted oncolytic adenoviruses for the treatment of HCC. Indeed, in HepG2, PC-OV displayed enhanced infectivity and improved anticancer properties over naked OV, suggesting that coating with targeting polymer can be properly exploited to enhance the efficacy of oncolytic virotherapy in cancer treatment.

\subsection{Oncolytic Viruses Coated with Galactosylated Polymers Induce Immunogenic Cell Death (ICD)}

Cancer development and spread is a process of biological evolution that consists of genetic changes and various adaptations. Different mutations confer a specific benefit 
depending on the changes in the tumor microenvironment. It has been reported that, in general, the success of the anticancer pharmacological therapies relies on the induction of immunogenic cell death (ICD) and the development of antitumor immune responses [58]. Cells undergo induction of ICD due to endoplasmic reticulum (ER) stress and reactive oxygen species (ROS) production as components for the exposure of different damageassociated molecular pathways (DAMPs) [59]. After the induction of ICD, chronic exposure of DAMPs on cancer cells attracts receptors and ligands on dendritic cells (DCs) and activates DCs to transition to a mature phenotype, which consequently results in stimulating specific $\mathrm{T}$ cell responses and subsequent killing of more cancer cells.

Similar to a few therapeutic agents, OVs are potent ICD activators enhancing the anticancer immune response [60] that contributes to antitumor efficacy. Furthermore, oncolytic adenoviruses can be genetically modified to complement mutations within the signaling pathways of ICD, resulting in clinical benefits. In particular, OVs can be constructed to produce caspase-8 in order to sensitize ICD resistant cancer types [59]. ICD relies on DAMPs and the signaling pathways that mediate the overexpression of ICD biomarkers, such as calreticulin (CRT), in the outer plasma membrane, followed by the extracellular release of high-mobility group box 1 protein (HMGB1) and adenosine triphosphate (ATP) [61,62]. Therefore, to evaluate whether a program of immunogenic cell death is triggered by OV treatments, the presence of HMGB1 and adenosine ATP in the supernatants is assessed [58,63].

Figure 5 reports the levels of ICD marker released by HepG2 and A549 cells treated with the same OV and/or $\mathrm{Gal}_{32}-b$ - $\mathrm{Agm}_{29}$ concentrations of naked OV, PC-OV, Gal $32-b-$ $\mathrm{Agm}_{29}$ alone, and $\mathrm{Gal}_{32}-b-\mathrm{Agm}_{29} / \mathrm{OV}$ mix.

A

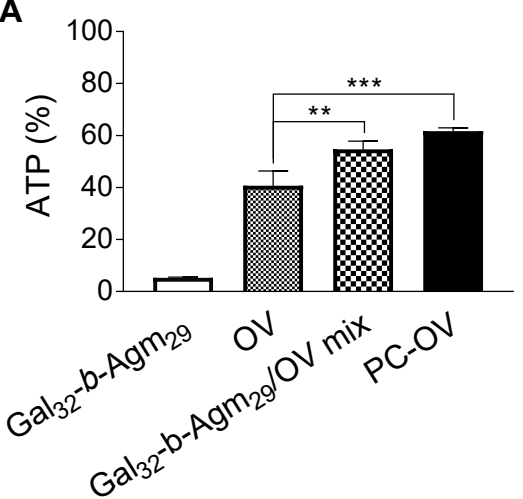

C

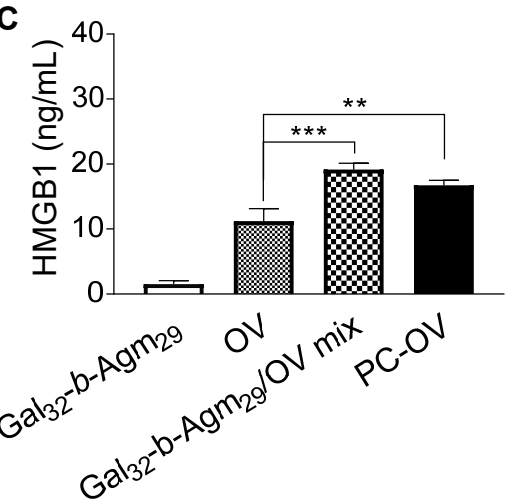

B

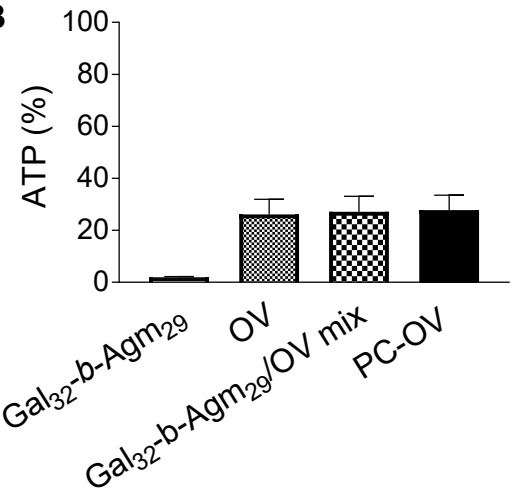

D

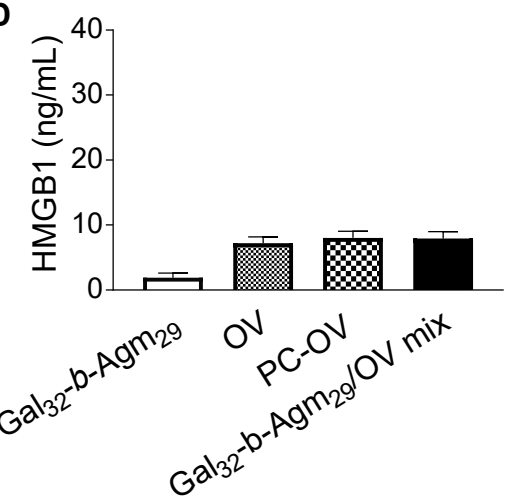

Figure 5. In vitro immunogenic tumor cell death. Extracellular ATP $(\mathbf{A}, \mathbf{B})$ in the supernatant of HepG2 (A) and A549 (B) cells after $48 \mathrm{~h}$ of treatment. Extracellular HMGB1 (C,D) in the supernatant of HepG2 (C) and A549 (D) cells after $72 \mathrm{~h}$ of treatment. Error bars, mean \pm SEM: ${ }^{* *} p<0.01$, $* * * p<0.001$. 
The results reported in Figure 5 show that $\mathrm{Gal}_{32}-b$ - $\mathrm{Agm}_{29}$ alone did not elicit significant expression of the ICD markers, which confirmed the excellent biocompatibility of this copolymer, while all samples containing OV (naked OV, PC-OV, and $\mathrm{Gal}_{32}-b-\mathrm{Agm}_{29} / \mathrm{OV}$ mix) were found to elicit relevant expression of ICD markers.

The higher release of the ICD marker in HepG2 cells as compared to A549 cells observed with all samples containing OV can be explained by the different ICD sensitivity of the two cell lines. Indeed, although both lung adenocarcinoma (A549) and HCC (HepG2) are immunogenic tumors [64], HepG2 might be more sensitive than A549 to changes induced by the virus infection resulting in the higher release of ICD markers, similarly to what is reported in the literature with other cell lines [61].

In the case of HepG2 cells, the highest immunogenic cell death was observed with PC-OV, which yielded higher levels of ATP $(60 \%)$ and HMGB1 $(20 \%)$ as compared to A549 cells (28\% ATP and 8\% HMGB1). Furthermore, in A549 no significant differences were observed among the various treatments. These results suggest that the presence of galactosylated polymer improves the OV delivery into HCC cells, thus boosting the infectivity and enhancing the in vitro therapeutic efficacy through the increased release of ATP and HMGB1.

\section{Conclusions}

In this study, we supported the use of cationic galactosylated polymers as carriers for the systemic delivery of oncolytic adenoviruses in the hepatocellular carcinoma cell line. Our results demonstrated the ability of OVs complexed with $\mathrm{Gal}_{32}-b-\mathrm{Agm}_{29}$ to improve the virus cell entry, thus enhancing viral replication that ultimately leads to the cancer cell lyses and higher immunogenic cell death induction program in the hepatocellular carcinoma cell line.

Altogether, here, we have proved that the use of galactosylated polymers for both coating and targeting is a safe and efficacious therapeutic strategy that minimizes side effects. Obtained results provide a rationale for future studies utilizing oncolytic viruses complexed with polymers towards specific and more effective targeting of HCC.

Supplementary Materials: The following are available online at https:/ / www.mdpi.com/article/10.3 390/pharmaceutics13070949/s1, Scheme S1: Synthesis of DMTMM; Scheme S2: Synthesis of 4-cyano-4(ethylsulfanylthiocarbonylsulfanyl)pentanoic acid; Scheme S3. Synthesis of D-galactopyranosyloxyethyl acrylamide; Scheme S4: Synthesis of agmatine acrylamide; Scheme S5: Synthesis of Cy5-Gal $32-b-$ Agm $_{29}$ by coupling reaction; Figure S1: ${ }^{1} \mathrm{H}$ NMR of CDMT in $\mathrm{CDCl}_{3}$; Figure S2: ${ }^{13} \mathrm{C}$ NMR of CDMT in $\mathrm{CDCl}_{3}$; Figure S3: ${ }^{1} \mathrm{H}$ NMR of DMTMM in $\mathrm{MeOH}_{-}{ }_{4}$; Figure S4: ${ }^{13} \mathrm{C}$ NMR of DMTMM in MeOH- ${ }^{4}$; Figure S5: ${ }^{1} \mathrm{H}$ NMR in $\mathrm{CDCl}_{3}$ of purified 4-cyano-4(ethylsulfanylthiocarbonylsulfanyl)pentanoic acid; Figure S6: ${ }^{13} \mathrm{C} \mathrm{NMR}$ in $\mathrm{CDCl}_{3}$ of purified 4-cyano-4(ethylsulfanylthiocarbonylsulfanyl)pentanoic acid; Figure S7: ${ }^{1} \mathrm{H}$ NMR of $\beta$-D-galactopyranosyloxyethyl acrylamide in DMSO- $d 6$ after purification; Figure S8: ${ }^{13} \mathrm{C}$ NMR of $\beta$-D-galactopyranosyloxyethyl acrylamide in DMSO- $d 6$ after purification; Figure S9: ${ }^{1} \mathrm{H}$ NMR of agmatine acrylamide in $\mathrm{D}_{2} \mathrm{O}$ after purification; Figure S10: ${ }^{13} \mathrm{C}$ NMR of agmatine acrylamide in $\mathrm{D}_{2} \mathrm{O}$ after purification; Figure S11: ${ }^{1} \mathrm{H}$ NMR in DMSO- $d 6$ of macro-CTA $\mathrm{Gal}_{32}$; Figure S12: ${ }^{1} \mathrm{H}$ NMR in DMSO- ${ }_{d 6}$ of $\mathrm{Gal}_{32}-b$-Agm 29 block copolymer after purification by dialysis; Figure S13: Gel permeation chromatography (GPC) profile of $\mathrm{Gal}_{32}-b$-Agm 29 (9) block copolymer after purification by dialysis and freeze-drying; Figure S14: Positive cells for CAR and DSG2 measured via flow cytometry by specific antibody staining; Figure S15: In vitro cytotoxicity on HepG2 cells at increasing concentration of serum; Figure S16: Dot plot with percentage of Annexin V/PI positive HepG2 and A549 cells; Figure S17: Representative flow cytometry analysis of Annexin V/ PI assay performed on HepG2 and A549 cells. 
Author Contributions: Conceptualization, M.G. and F.M.; methodology, M.G., L.K. and B.R. for the biological assays, F.B., S.M. and F.M. for the polymer synthesis.; validation, M.G. and F.M.; formal analysis, A.M., S.N., L.K., B.R., F.B., S.M., M.G. and F.M.; investigation, F.B., S.M., M.G., A.M., S.N., L.K., S.S., B.R. and F.M.; resources, P.C., M.G. and F.M.; data curation, M.G. and F.M.; writing-original draft preparation, P.C., F.B., M.G. and F.M.; writing-review and editing, S.S., P.C. and F.M.; supervision, F.M.; project administration, M.G. and F.M.; funding acquisition, L.K., M.G. and F.M. All authors have read and agreed to the published version of the manuscript.

Funding: This research was funded by STARS Starting Grants (STARS StG)" (grant no. MAST_STARS18_02, CUP C91I18001190005); PRIDJ (grant no. MAST_SID17_01, CUP C93C17002300005); PRID-J (grant no: GARO_SID19_02); National Science Center, Poland: SONATINA (2019/32/C/NZ7/00156); National Institute of Public Health-National Institute of Hygiene, Poland (BW-4/2020 and 1BWBW/2021).

Institutional Review Board Statement: Not applicable.

Informed Consent Statement: Not applicable.

Data Availability Statement: Not applicable.

Acknowledgments: The graphical abstract was created with BioRender.com (accessed on 1 May 2021).

Conflicts of Interest: L. Kuryk is an employee of Targovax Oy in Finland. The Targovax Oy had no role in the design of the study; in the collection, analyses, or interpretation of data; in the writing of the manuscript, or in the decision to publish the results. All the other authors declare no potential conflict of interest.

\section{References}

1. Jemal, A.; Siegel, R.; Ward, E.; Hao, Y. Cancer Statistics. CA Cancer J. Clin. 2008, 58, 71-96. [CrossRef]

2. Goh, G.B.-B.; Chang, P.-E.; Tan, C.-K. Changing epidemiology of hepatocellular carcinoma in Asia. Best Pract. Res. Clin. Gastroenterol. 2015, 29, 919-928. [CrossRef]

3. Donne, R.; Saroul-Aïnama, M.; Cordier, P.; Celton-Morizur, S.; Desdouets, C. Polyploidy in liver development, homeostasis and disease. Nat. Rev. Gastroenterol. Hepatol. 2020, 17, 391-405. [CrossRef] [PubMed]

4. Fung, J.; Lai, C.L.; Yuen, M.F. Hepatitis B and C virus-related carcinogenesis. Clin. Microbiol. Infect. 2009, 15, 964-970. [CrossRef] [PubMed]

5. Blonski, W.; Kotlyar, D.S.; Forde, K.A. Non-viral causes of hepatocellular carcinoma. World J. Gastroenterol. 2010, 16, 3603-3615. [CrossRef] [PubMed]

6. Tsai, W.L.; Chung, R.T. Viral hepatocarcinogenesis. Oncogene 2010, 29, 2309-2324. [CrossRef]

7. Daher, S.; Massarwa, M.; Benson, A.A.; Khoury, T. Current and Future Treatment of Hepatocellular Carcinoma: An Updated Comprehensive Review. J. Clin. Transl. Hepatol. 2018, 6, 69-78. [CrossRef]

8. Balasso, A.; Salmaso, S.; Pontisso, P.; Rosato, A.; Quarta, S.; Malfanti, A.; Mastrotto, F.; Caliceti, P. Re-programming pullulan for targeting and controlled release of doxorubicin to the hepatocellular carcinoma cells. Eur. J. Pharm. Sci. 2017, 103, 104-115. [CrossRef]

9. Baig, B.; Halim, S.A.; Farrukh, A.; Greish, Y.; Amin, A. Current status of nanomaterial-based treatment for hepatocellular carcinoma. Biomed. Pharm. 2019, 116, 108852. [CrossRef]

10. Capasso, C.; Hirvinen, M.; Garofalo, M.; Romaniuk, D.; Kuryk, L.; Sarvela, T.; Vitale, A.; Antopolsky, M.; Magarkar, A.; Viitala, T.; et al. Oncolytic adenoviruses coated with MHC-I tumor epitopes increase the antitumor immunity and efficacy against melanoma. Oncoimmunology 2016, 5, 1-11. [CrossRef]

11. Garofalo, M.; Villa, A.; Rizzi, N.; Kuryk, L.; Mazzaferro, V.; Ciana, P. Systemic Administration and Targeted Delivery of Immunogenic Oncolytic Adenovirus Encapsulated in Extracellular Vesicles for Cancer Therapies. Viruses 2018, 10, 558. [CrossRef]

12. Capasso, C.; Magarkar, A.; Cervera-Carrascon, V.; Fusciello, M.; Feola, S.; Muller, M.; Garofalo, M.; Kuryk, L.; Tahtinen, S.; Pastore, L.; et al. A novel in silico framework to improve MHC-I epitopes and break the tolerance to melanoma. Oncoimmunology 2017, 6, e1319028. [CrossRef] [PubMed]

13. Garofalo, M.; Villa, A.; Brunialti, E.; Crescenti, D.; Dell'Omo, G.; Kuryk, L.; Vingiani, A.; Mazzaferro, V.; Ciana, P. Cancer-derived EVs show tropism for tissues at early stage of neoplastic transformation. Nanotheranostics 2021, 5, 1-7. [CrossRef] [PubMed]

14. Kuryk, L.; Bertinato, L.; Staniszewska, M.; Pancer, K.; Wieczorek, M.; Salmaso, S.; Caliceti, P.; Garofalo, M. From Conventional Therapies to Immunotherapy: Melanoma Treatment in Review. Cancers 2020, 12, 3057. [CrossRef]

15. Yamamoto, M.; Curiel, D.T. Current Issues and Future Directions of Oncolytic Adenoviruses. Mol. Ther. 2010, 18, 243-250. [CrossRef]

16. Kuryk, L.; Møller, A.-S.W.; Garofalo, M.; Cerullo, V.; Pesonen, S.; Alemany, R.; Jaderberg, M. Anti-tumor specific T-cell responses induced by oncolytic adenovirus ONCOS-102 in peritoneal mesothelioma mouse model. J. Med. Virol. 2018, 90, 1-5. [CrossRef]

17. Kuryk, L.; Møller, A.-S.W.; Jaderberg, M. Abscopal effect when combining oncolytic adenovirus and checkpoint inhibitor in a humanized NOG mouse model of melanoma. J. Med. Virol. 2019, 91, 1702-1706. [CrossRef] 
18. Kuryk, L.; Møller, A.-S.; Vuolanto, A.; Pesonen, S.; Garofalo, M.; Cerullo, V.; Jaderberg, M. Optimization of Early Steps in Oncolytic Adenovirus ONCOS-401 Production in T-175 and HYPERFlasks. Int. J. Mol. Sci. 2019, 20, 621. [CrossRef]

19. Jing, Y.; Chavez, V.; Khatwani, N.; Ban, Y.; Espejo, A.P.; Chen, X.; Merchan, J.R. In vivo antitumor activity by dual stromal and tumor-targeted oncolytic measles viruses. Cancer Gene Ther. 2020. [CrossRef] [PubMed]

20. Kuryk, L.; Vassilev, L.; Ranki, T.; Hemminki, A.; Karioja-Kallio, A.; Levalampi, O.; Vuolanto, A.; Cerullo, V.; Pesonen, S. Toxicological and bio-distribution profile of a GM-CSF-expressing, double-targeted, chimeric oncolytic adenovirus ONCOS-102-Support for clinical studies on advanced cancer treatment. PLoS ONE 2017, 12, e0182715. [CrossRef]

21. Kaufman, H.L. Two roads for oncolytic immunotherapy development. J. Immunother. Cancer 2019, 2, 1-5. [CrossRef] [PubMed]

22. Bommareddy, P.K.; Patel, A.; Hossain, S.; Kaufman, H.L. Talimogene Laherparepvec (T-VEC) and Other Oncolytic Viruses for the Treatment of Melanoma. Am. J. Clin. Dermatol. 2017, 18, 1-15. [CrossRef]

23. Abudoureyimu, M.; Lai, Y.; Tian, C.; Wang, T.; Wang, R.; Chu, X. Oncolytic Adenovirus-A Nova for Gene-Targeted Oncolytic Viral Therapy in HCC. Front. Oncol. 2019, 9, 1182. [CrossRef] [PubMed]

24. Zou, H.; Zheng, Y.-F.; Ge, W.; Wang, S.-B.; Mou, X.-Z. Synergistic Anti-tumour Effects of Quercetin and Oncolytic Adenovirus expressing TRAIL in Human Hepatocellular Carcinoma. Sci. Rep. 2018, 8, 1-8. [CrossRef] [PubMed]

25. Yoon, A.R.; Hong, J.; Kim, M.; Yun, C.-O. Hepatocellular carcinoma-targeting oncolytic adenovirus overcomes hypoxic tumor microenvironment and effectively disperses through both central and peripheral tumor regions. Sci. Rep. 2018, 8, 1-14. [CrossRef] [PubMed]

26. Zhang, Z.; Krimmel, J.; Zhang, Z.; Hu, Z.; Seth, P. Systemic Delivery of a Novel Liver-Detargeted Oncolytic Adenovirus Causes Reduced Liver Toxicity but Maintains the Antitumor Response in a Breast Cancer Bone Metastasis Model. Hum. Gene Ther. 2011, 22, 1137-1142. [CrossRef]

27. Hong, J.; Yun, C.-O. Overcoming the limitations of locally administered oncolytic virotherapy. BMC Biomed. Eng. 2019, 1, 1-11. [CrossRef]

28. D'Souza, A.A.; Devarajan, P.V. Asialoglycoprotein receptor mediated hepatocyte targeting-Strategies and applications. J. Control. Release 2015, 203, 126-139. [CrossRef]

29. Thapa, B.; Kumar, P.; Zeng, H.; Narain, R. Asialoglycoprotein Receptor-Mediated Gene Delivery to Hepatocytes Using Galactosylated Polymers. Biomacromolecules 2015, 16, 3008-3020. [CrossRef]

30. Cronin, J.S.; Ginah, F.O.; Murray, A.R.; Copp, J.D. An Improved Procedure for the Large Scale Preparation of 2-Chloro-4,6dimethoxy-1,3,5-triazine. Synth. Commun. 1996, 26, 3491-3494. [CrossRef]

31. Kunishima, M.; Kawachi, C.; Monta, J.; Terao, K.; Iwasaki, F.; Tani, S. 4-(4,6-dimethoxy-1,3,5-triazin-2-yl)-4-methyl-morpholinium chloride: An efficient condensing agent leading to the formation of amides and esters. Tetrahedron 1999, 55, 13159-13170. [CrossRef]

32. Truong, N.P.; Dussert, M.V.; Whittaker, M.R.; Quinn, J.F.; Davis, T.P. Rapid synthesis of ultrahigh molecular weight and low polydispersity polystyrene diblock copolymers by RAFT-mediated emulsion polymerization. Polym. Chem. 2015, 6, 3865-3874. [CrossRef]

33. Luisa, M.-P.F.M.; Giuseppe, M. Sulfated Glycopolymers. Patent WO/2018/007827, 11 January 2018.

34. Mattias, A.P.B.; Nicolas, T. Method for Synthesis of Acrylamide Derivatives. U.S. Patent 7,294,743, 13 November 2007.

35. Gody, G.; Maschmeyer, T.; Zetterlund, P.B.; Perrier, S. Pushing the Limit of the RAFT Process: Multiblock Copolymers by One-Pot Rapid Multiple Chain Extensions at Full Monomer Conversion. Macromolecules 2014, 47, 3451-3460. [CrossRef]

36. Mastrotto, F.; Breen, A.F.; Sicilia, G.; Murdan, S.; Johnstone, A.D.; Marsh, G.E.; Grainger-Boultby, C.; Russell, N.A.; Alexander, C.; Mantovani, G. One-pot RAFT and fast polymersomes assembly: A 'beeline' from monomers to drug-loaded nanovectors. Polym. Chem. 2016, 7, 6714-6724. [CrossRef]

37. Kanerva, A.; Zinn, K.R.; Chaudhuri, T.R.; Lam, J.T.; Suzuki, K.; Uil, T.G.; Hakkarainen, T.; Bauerschmitz, G.J.; Wang, M.; Liu, B.; et al. Enhanced therapeutic efficacy for ovarian cancer with a serotype 3 receptor-targeted oncolytic adenovirus. Mol. Ther. 2003, 8, 449-458. [CrossRef]

38. Kanerva, A.; Hemminki, A. Modified adenoviruses for cancer gene therapy. Int. J. Cancer 2004, 110, 475-480. [CrossRef] [PubMed]

39. Kuryk, L.; Møller, A.-S.W.; Jaderberg, M. Quantification and functional evaluation of CD40L production from the adenovirus vector ONCOS-401. Cancer Gene Ther. 2019, 26, 26-31. [CrossRef] [PubMed]

40. Garofalo, M.; Bertinato, L.; Staniszewska, M.; Wieczorek, M.; Salmaso, S.; Schrom, S.; Rinner, B.; Pancer, K.W.; Kuryk, L. Combination Therapy of Novel Oncolytic Adenovirus with Anti-PD1 Resulted in Enhanced Anti-Cancer Effect in Syngeneic Immunocompetent Melanoma Mouse Model. Pharmaceutics 2021, 13, 547. [CrossRef] [PubMed]

41. Koski, A.; Kangasniemi, L.; Escutenaire, S.; Pesonen, S.; Cerullo, V.; Diaconu, I.; Nokisalmi, P.; Raki, M.; Rajecki, M.; Guse, K.; et al. Treatment of cancer patients with a serotype 5/3 chimeric oncolytic adenovirus expressing GMCSF. Mol. Ther. J. Am. Soc. Gene Ther. 2010, 18, 1874-1884. [CrossRef] [PubMed]

42. Kuryk, L.; Møller, A.-S.W. Chimeric oncolytic Ad5/3 virus replicates and lyses ovarian cancer cells through desmoglein-2 cell entry receptor. J. Med. Virol. 2020, 92, 1309-1315. [CrossRef]

43. Garofalo, M.; Iovine, B.; Kuryk, L.; Capasso, C.; Hirvinen, M.; Vitale, A.; Yliperttula, M.; Bevilacqua, M.A.; Cerullo, V. Oncolytic Adenovirus Loaded with L-carnosine as Novel Strategy to Enhance the Antitumor Activity. Mol. Cancer Ther. 2016, 15, 651-660. [CrossRef] 
44. Yousef, S.; Alsaab, H.O.; Sau, S.; Iyer, A.K. Development of asialoglycoprotein receptor directed nanoparticles for selective delivery of curcumin derivative to hepatocellular carcinoma. Heliyon 2018, 4, e01071. [CrossRef]

45. Weigels, P.H.; Oka, J.A. The Large Intracellular Pool of Asialoglycoprotein Receptors Functions during the Endocytosis of Asialoglycoproteins by Isolated Rat Hepatocytes. J. Biol. Chem. 1983, 258, 5095-5102. [CrossRef]

46. Rice, K.G.; Lee, Y.C. Oligosaccharide Valency and Conformation in Determining Binding to the Asialoglycoprotein Receptor of Rat Hepatocytes. Adv. Enzymol. Relat. Areas Mol. Biol. 1993, 66, 41-83. [CrossRef] [PubMed]

47. Jiang, X.; van der Horst, A.; van Steenbergen, M.J.; Akeroyd, N.; van Nostrum, C.F.; Schoenmakers, P.J.; Hennink, W.E. Molar-Mass Characterization of Cationic Polymers for Gene Delivery by Aqueous Size-Exclusion Chromatography. Pharm. Res. 2006, 23, 595-603. [CrossRef] [PubMed]

48. Xing, H.; Lu, M.; Xian, L.; Zhang, J.; Yang, T.; Yang, L.; Ding, P. Molecular weight determination of a newly synthesized guanidinylated disulfide-containing poly(amido amine) by gel permeation chromatography. Asian J. Pharm. Sci. 2017, 12, 292-298. [CrossRef] [PubMed]

49. Fasbender, A.; Zabner, J.; Chillo, M.; Moninger, T.O.; Puga, A.P.; Davidson, B.L.; Welsh, M.J. Complexes of Adenovirus with Polycationic Polymers and Cationic Lipids Increase the Efficiency of Gene Transfer in Vitro and in Vivo. J. Biol. Chem. 1997, 272, 6479-6489. [CrossRef] [PubMed]

50. Fisher, K.D.; Stallwood, Y.; Green, N.K.; Ulbrich, K.; Mautner, V.; Seymour, L.W. Polymer-coated adenovirus permits efficient retargeting and evades neutralising antibodies. Gene Ther. 2001, 8, 341-348. [CrossRef]

51. Nikitin, N.; Trifonova, E.; Evtushenko, E.; Kirpichnikov, M.; Atabekov, J.; Karpova, O. Comparative Study of Non-Enveloped Icosahedral Viruses Size. PLoS ONE 2015, 10, e0142415. [CrossRef]

52. Harris, R.L.; van den Berg, C.W.; Bowen, D.J. ASGR1 and ASGR2, the Genes that Encode the Asialoglycoprotein Receptor (Ashwell Receptor), Are Expressed in Peripheral Blood Monocytes and Show Interindividual Differences in Transcript Profile. Mol. Biol. Int. 2012, 2012, 283974. [CrossRef]

53. Peng, D.-J.; Sun, J.; Wang, Y.-Z.; Tian, J.; Zhang, Y.-H.; Noteborn, M.H.M.; Qu, S. Inhibition of hepatocarcinoma by systemic delivery of Apoptin gene via the hepatic asialoglycoprotein receptor. Cancer Gene Ther. 2007, 14, 66-73. [CrossRef] [PubMed]

54. Segerman, A.; Atkinson, J.P.; Marttila, M.; Dennerquist, V.; Wadell, G.; Arnberg, N. Adenovirus Type 11 Uses CD46 as a Cellular Receptor. J. Virol. 2003, 77, 9183-9191. [CrossRef] [PubMed]

55. Stasiak, A.C.; Stehle, T. Human adenovirus binding to host cell receptors: A structural view. Med. Microbiol. Immunol. 2020, 209, 325-333. [CrossRef]

56. Gao, J.; Zhang, W.; Mese, K.; Bunz, O.; Lu, F.; Ehrhardt, A. Transient Chimeric Ad5/37 Fiber Enhances NK-92 Carrier CellMediated Delivery of Oncolytic Adenovirus Type 5 to Tumor Cells. Mol. Ther. Methods Clin. Dev. 2020, 18, 376-389. [CrossRef]

57. Bersani, S.; Salmaso, S.; Mastrotto, F.; Ravazzolo, E.; Semenzato, A.; Caliceti, P. Star-Like Oligo-Arginyl-Maltotriosyl Derivatives as Novel Cell-Penetrating Enhancers for the Intracellular Delivery of Colloidal Therapeutic Systems. Bioconjugate Chem. 2012, 23, 1415-1425. [CrossRef]

58. Kepp, O.; Senovilla, L.; Vitale, I. Consensus guidelines for the detection of immunogenic cell death. OncoImmunology 2014, 3, e955691. [CrossRef]

59. Workenhe, S.T.; Mossman, K.L. Oncolytic Virotherapy and Immunogenic Cancer Cell Death: Sharpening the Sword for Improved Cancer Treatment Strategies. Mol. Ther. 2014, 22, 251-256. [CrossRef]

60. Garofalo, M.; Staniszewska, M.; Salmaso, S.; Caliceti, P.; Pancer, K.W.; Wieczorek, M.; Kuryk, L. Prospects of Replication-Deficient Adenovirus Based Vaccine Development against SARS-CoV-2. Vaccines 2020, 8, 293. [CrossRef]

61. Kuryk, L.; Haavisto, E.; Garofalo, M.; Capasso, C.; Hirvinen, M.; Pesonen, S.; Ranki, T.; Vassilev, L.; Cerullo, V. Synergistic anti-tumor efficacy of immunogenic adenovirus ONCOS-102 (Ad5/3-D24-GM-CSF) and standard of care chemotherapy in preclinical mesothelioma model. Int. J. Cancer 2016, 139, 1883-1893. [CrossRef] [PubMed]

62. Kuryk, L. Combination of immunogenic oncolytic adenovirus ONCOS-102 with anti-PD-1 pembrolizumab exhibits synergistic antitumor effect in humanized A2058 melanoma huNOG mouse model. Oncoimmunology 2019, 8, e1532763. [CrossRef]

63. Kroemer, G.; Galluzzi, L.; Kepp, O.; Zitvogel, L. Immunogenic Cell Death in Cancer Therapy. Annu. Rev. Immunol. 2013, 31, 51-72. [CrossRef] [PubMed]

64. Wang, C.; Chen, T. Intratumoral injection of taxol in vivo suppresses A549 tumor showing cytoplasmic vacuolization. J. Cell. Biochem. 2012, 113, 1397-1406. [CrossRef] [PubMed] 